\title{
Analysis of phenolic compounds from different morphological parts of Helichrysum devium by liquid chromatography with on-line UV and electrospray ionization mass spectrometric detection
}

\author{
Sandra C. Gouveia and Paula C. Castilho* \\ Centro de Química da Madeira, Departamento de Química, Universidade da Madeira, Campus da Penteada, 9000-390 Funchal, Portugal
}

Received 11 July 2009; Revised 30 September 2009; Accepted 11 October 2009

\begin{abstract}
A simple and rapid method has been used for the screening and identification of the main phenolic compounds from Helichrysum devium using high-performance liquid chromatography with on-line UV and electrospray ionization mass spectrometric detection (LC-DAD/ESI-MS ${ }^{\mathrm{n}}$ ). The total aerial parts and different morphological parts of the plant, namely leaves, flowers and stems, were analyzed separately. A total of 34 compounds present in the methanolic extract from Helichrysum devium were identified or tentatively characterized based on their UV and mass spectra and retention times. Three of these compounds were positively identified by comparison with reference standards. The phenolic compounds included derivatives of quinic acid, $O$-glycosylated flavonoids, a caffeic acid derivative and a protocatechuic acid derivative. The characteristic loss of $206 \mathrm{Da}$ from malonylcaffeoyl quinic acid was used to confirm the malonyl linkage to the caffeoyl group. This contribution presents one of the first reports on the analysis of phenolic compounds from Helichrysum devium using LC-DAD/ ESI-MS ${ }^{n}$ and highlights the prominence of quinic acid derivatives as the main group of phenolic compounds present in these extracts. We also provide evidence that the methanolic extract from the flowers was significantly more complex when compared to that of other morphological parts. Copyright (C) 2009 John Wiley \& Sons, Ltd.
\end{abstract}

Plants of the genus Helichrysum belong to the Asteraceae family, a name originating from the Greek words helios (sun) and chrysos (gold) that reflect the attractive yellow flowers displayed by several species of these genus. ${ }^{1}$ This genus comprises more than 500 species mainly distributed in South Africa, although many endemic species can be found in southern Europe, south-west Asia, southern India, Sri Lanka and Australia. Several studies performed on Helichrysum species showed that they have a wide range of biological activities, such as antimicrobial, anti-inflammatory, antiallergic, relief abdominal pain, heart burn, cough, cold and wounds. $^{2}$

In Madeira Archipelago (Portugal) there are four endemic species together with several imported species of Helichrysum that are mostly used in horticulture and in folk medicine, especially in rural areas. Helichrysum devium Johns., the subject of this investigation, is one of those endemic subspecies that is used in folk medicine against respiratory diseases, such as bronchitis and pharyngitis. This plant faced near extinction due to massive collection of wild specimens. Fortunately, a successful programme of green house

*Correspondence to: P. C. Castilho, Centro de Química da Madeira, Departamento de Química, Universidade da Madeira, Campus Universitário da Penteada, piso 0, 9000-390 Funchal, Portugal.

E-mail: castilho@uma.pt reproduction has facilitated its re-introduction in its natural habitat on the rocky slopes of the south-east cost of the island of Madeira.

The pharmacological activities of Helichrysum plants have been associated to several classes of compounds such as flavonoids, phloroglucinols, $\alpha$-pyrones, coumarins and terpenoids which have been previously described. ${ }^{3}$ Previous studies have reported the occurrence of quinic acid derivatives esterified with one to three residues of caffeic acid. $^{2,4}$ A few studies using analysis by liquid chromatography with diode-array detection coupled with mass spectrometric detection (LC-DAD/MS ${ }^{\mathrm{n}}$ ) also described the characterization of phenolic compounds from Helichrysum species. Carini et al. ${ }^{2}$ studied Helichrysum stoechas and found the presence of some phenolic compounds, namely caffeoylquinic acid and flavonol derivatives, with potent antioxidant properties.

Phenolic compounds are a class of low molecular weight compounds which are secondary metabolites synthesized by the plants during normal development and in response to stress conditions like infection, wounding and UV radiation. ${ }^{5}$ These compounds are not only associated with the colour, flavour and taste in many plants, but are also reported to have valuable medicinal properties such as protection against cancer, cardiovascular and neurodegenerative dis- 
eases. ${ }^{6}$ For these reasons, many studies have been performed in order to identify and characterize phenolic compounds from natural sources.

The main classes of phenolic compounds are flavonoids and phenolic acids (e.g. hydroxybenzoic and hydroxycinnamic acids).

Flavonoid conjugates represent a very large and diverse group of phenolic compounds with similar structure having a common C6-C3-C6 flavone skeleton. ${ }^{7}$ In cell plants, flavonoids may occur in modified forms corresponding to additional hydroxylation, methylation and/or glycosylation. It is also possible to have aromatic and aliphatic acids, sulfate, prenyl, methylenedioxyl or acyl groups also attached to the flavonoid skeleton or its glycoside moieties. Flavonoid glycosides are the most common phenolic compounds and are divided according to the site of the flavonoid aglycone where the sugar moiety is attached. O-Glycosides have glycoside groups connected to hydroxyl groups while in the $\mathrm{C}$-glycosides the sugar bond connects the carbon atoms in ring $\mathrm{A}$.

Since phenolic compounds are usually found as complex mixtures in plant extracts, efficient and selective analytical methods are required to analyze them. Liquid chromatography coupled to tandem mass spectrometry (LC/MS/MS) with electrospray ionization (ESI) or atmospheric pressure chemical ionization (APCI) has proved to be a very powerful tool for the analysis of these compounds. According to several studies, using either APCI or ESI, the negative ionization mode typically provides enhanced sensitivity and yields complementary information. However, detection in the positive ion mode provides useful structural information for MS/MS characterization. A comparison between ESI and APCI indicated that the latter ionization mode is favoured for the analysis of phenolic compounds of plant extracts due to its higher ionization efficiency and selectivity for these compounds. ${ }^{8-10}$ The mass spectra of flavonoids obtained with quadrupole and ion-trap instruments are typically very similar, even though differences in the relative abundances of fragment and adduct ions have been noted. ${ }^{11}$

The aim of this work was to characterize by LC-DAD/ESI$\mathrm{MS}^{\mathrm{n}}$ the main phenolic compounds present in the methanolic extracts of Helichrysum devium. Since the use of this plant in folk medicine shows variation in activity depending on the parts of the plant used (flowers only, leaves only or total aerial parts), it is important to evaluate the distribution of phenolic compounds in different morphological parts and correlate their contribution to the biological activity. As part of this study we used negative ion mode in LC/MS and LC/ $\mathrm{MS}^{\mathrm{n}}$ analysis. A total of 34 compounds were identified or tentatively characterized, including flavonoids and quinic acid derivatives. This work represents a first detailed analysis on the distribution and characterization of these bioactive compounds from the different parts of the plant.

\section{EXPERIMENTAL}

\section{Chemical and materials}

Standards used for identification purposes with LC/ESI-MS ${ }^{\text {n }}$ were as follows: apigenin-7-O-glucoside (>99\%), apigenin
(>99\%), luteolin (>99\%), quercetin (>99\%) were purchased from ExtraSynthese and 5-O-caffeoylquinic acid (99\%), kaempferol (>99\%) from Acros Organics. Stock solutions of these compounds $(100 \mu \mathrm{g} / \mathrm{mL})$ were prepared in ethanol and further analysed by LC-DAD/ESI-MS ${ }^{\mathrm{n}}$.

HPLC grade acetonitrile $\left(\mathrm{CH}_{3} \mathrm{CN}\right)$ (Lab-Scan, 99\%) and ultra-pure water (Milli-Q, Waters) were used for all analysis. The methanol used for extraction of Helichrysum devium was AR grade, purchased from Fisher. Eluents prepared for LC/ MS analysis (formic acid $0.1 \%, \mathrm{v} / \mathrm{v}$ ) were additionally filtered through a $0.45 \mu \mathrm{m}$ membrane (Millipore).

\section{Sample preparation}

Samples of Helichrysum devium were collected in the wild and identified by taxonomist Fátima Rocha and a voucher was deposited in the Madeira Botanical Garden Herbarium collection. Dried and powdered plant material (total aerial parts, $100 \mathrm{~g}$ ) was exhaustively extracted by maceration with methanol $(1 \mathrm{~L})$, at room temperature for $24 \mathrm{~h}$, yielding $8.64 \mathrm{~g}$ of dry extract.

For assessment of morphological parts, the leaves, flowers and stems of the plant were collected, dried and powdered separately. Each sample was extracted sequentially with four solvents of increasing polarity ( $n$-hexane, chloroform, ethyl acetate and methanol), at room temperature for $24 \mathrm{~h}$.

In all cases the solutions were filtered and concentrated to dryness under reduced pressure in a rotary evaporator $\left(40^{\circ} \mathrm{C}\right)$. At this stage only methanolic extracts were used for the LC-DAD/ESI-MS ${ }^{n}$ analysis. Stock solutions with concentrations $(\mathrm{w} / \mathrm{v})$ of $5 \mathrm{mg} / \mathrm{mL}$ were prepared by dissolving dried extract in initial HPLC mobile phase (ACN/ $\mathrm{H}_{2} \mathrm{O}, 20: 80$ ).

These solutions were filtered through $0.45 \mu \mathrm{m}$ micropore membranes prior to use and volumes of $10 \mu \mathrm{L}$ were injected for LC-DAD/ESI-MS ${ }^{n}$ analysis. Three independent assays were performed for each sample.

\section{LC conditions}

HPLC analysis was performed on a Dionex ultimate 3000 series instrument coupled to a binary pump, a diode-array detector (DAD), an autosampler and a column compartment. The wavelength range was set at $210-520 \mathrm{~nm}$ and was monitored at $280 \mathrm{~nm}$. Samples were separated on a Phenomenex Gemini $\mathrm{C}_{18}$ column $(5 \mu \mathrm{m}, 250 \times 3.0 \mathrm{~mm}$ i.d., Phenomenex) with a sample injection volume of $10 \mu \mathrm{L}$. The mobile phase consisted of acetonitrile (A) and water/formic acid (100:0.1, v/v) (B). A gradient program was used as follows: $20 \% \mathrm{~A}(0 \mathrm{~min}), 25 \% \mathrm{~A}(10 \mathrm{~min}), 25 \% \mathrm{~A}$ (20 $\mathrm{min}), 50 \%$ A (40 min), $100 \%$ A (42-47 min), 20\% A (49-55 min). The mobile phase flow rate was $0.4 \mathrm{~mL} / \mathrm{min}$; the chromatogram was recorded at $280 \mathrm{~nm}$ and spectral data for all peaks were accumulated in the range of 190-400 nm. Column temperature was controlled at $30^{\circ} \mathrm{C}$.

\section{Mass spectrometric conditions}

For LC/ESI-MS analysis, a model 6000 ion trap mass spectrometer (Bruker Esquire, Bremen, Germany) fitted with an ESI source was used. Data acquisition and processing were performed using Esquire control software. Negative 
ion mass spectra of the column eluate were recorded in the range $m / z 100-1000$ at a scan speed of $13000 \mathrm{Da} / \mathrm{s}$. Highpurity nitrogen $\left(\mathrm{N}_{2}\right)$ was used both as drying gas at a flow of $10.0 \mathrm{~mL} / \mathrm{min}$ and as a nebulizing gas at a pressure of 50 psi. The nebulizer temperature was set at $365^{\circ} \mathrm{C}$ and a potential of $+4500 \mathrm{~V}$ was used on the capillary. Ultra-high-purity helium (He) was used as collision gas at a pressure of $1 \times 10^{-5} \mathrm{mbar}$ and the collision energy was set at $40 \mathrm{~V}$.

The acquisition of $\mathrm{MS}^{\mathrm{n}}$ data was made in auto $M S^{n}$ mode, with isolation width of $4.0 \mathrm{~m} / z$. For $\mathrm{MS}^{\mathrm{n}}$ analysis, the mass spectrometer was scanned from 10 to $1000 \mathrm{~m} / \mathrm{z}$ with a fragmentation amplitude of $1.0 \mathrm{~V}\left(\mathrm{MS}^{\mathrm{n}}\right.$ up to $\left.\mathrm{MS}^{4}\right)$ and two precursor ions.

\section{RESULTS AND DISCUSSION}

Three independent assays were performed for the analysis of the methanolic extracts from Helichrysum devium by LC$\mathrm{DAD} \mathrm{ESI}_{\mathrm{M}} \mathrm{MS}^{\mathrm{n}}$ and no relevant variation were observed that can be related to the nature of detected fragments and their relative intensities.

The base peak chromatogram profiles of the four methanolic extracts under analysis are shown in Fig. 1. As can be seen, the majority of compounds could be well separated.

Whenever possible, the HPLC retention time, UV and mass spectra of detected compounds were compared with reference standards. Because only a few reference compounds were available, structures of unknown compounds were characterized based mainly on their own $\mathrm{MS}^{\mathrm{n}}$ fragmentation behaviour, on retention times and on studies of their UV spectra.
The UV profile and spectral similarities were useful characteristics for the establishment of classes of detected compounds. The hydroxycinnamic acid derivatives showed two maximum absorption bands at 230-240 $\mathrm{nm}$ and 320$330 \mathrm{~nm}$, together with a shoulder around $300-310 \mathrm{~nm}$. Flavonols and their glycosides exhibited two maximum absorptions at $250-270 \mathrm{~nm}$ and $320-360 \mathrm{~nm}$, derived from the aglycone A and B rings, respectively. Peaks corresponding to flavone glycosides showed three absorptions at $210-230 \mathrm{~nm}$, 250-280 $\mathrm{nm}$ and 330-350 $\mathrm{nm}$.

The structures were further and more fully characterized based on their $\mathrm{MS}^{\mathrm{n}}$ fragmentation behaviour. $\mathrm{MS}^{\mathrm{n}}$ fragmentation ions of the compounds detected in all extracts are presented in Tables 1-4 and their chemical structures are shown in Fig. 2.

An essential step in the LC-DAD/ESI-MS ${ }^{\mathrm{n}}$ analysis was to determine the molecular weight of each detected compound. Most of the phenolic compounds gave deprotonated molecular ions $[\mathrm{M}-\mathrm{H}]^{-}$of high abundance, which allowed them to undergo $\mathrm{MS}^{\mathrm{n}}$ analysis. Usually, the most abundant peak in a full MS spectrum was assigned to $[\mathrm{M}-\mathrm{H}]^{-}$and this assignment was more consistent if adduct ions and dimers were present. ${ }^{12}$

Among the identified compounds, there were hydroxycinnamic acids, flavonoids (flavonol and flavone type), caffeic acid and a protocatechuic acid derivative.

Identification will be presented in the next subsections, grouping the compounds by the nature of the respective aglycones. Compounds were numbered by their order of elution and this numeration was kept identical for all samples. Some of the compounds were present in all analyzed extracts while some were absent from one or more morphological parts.

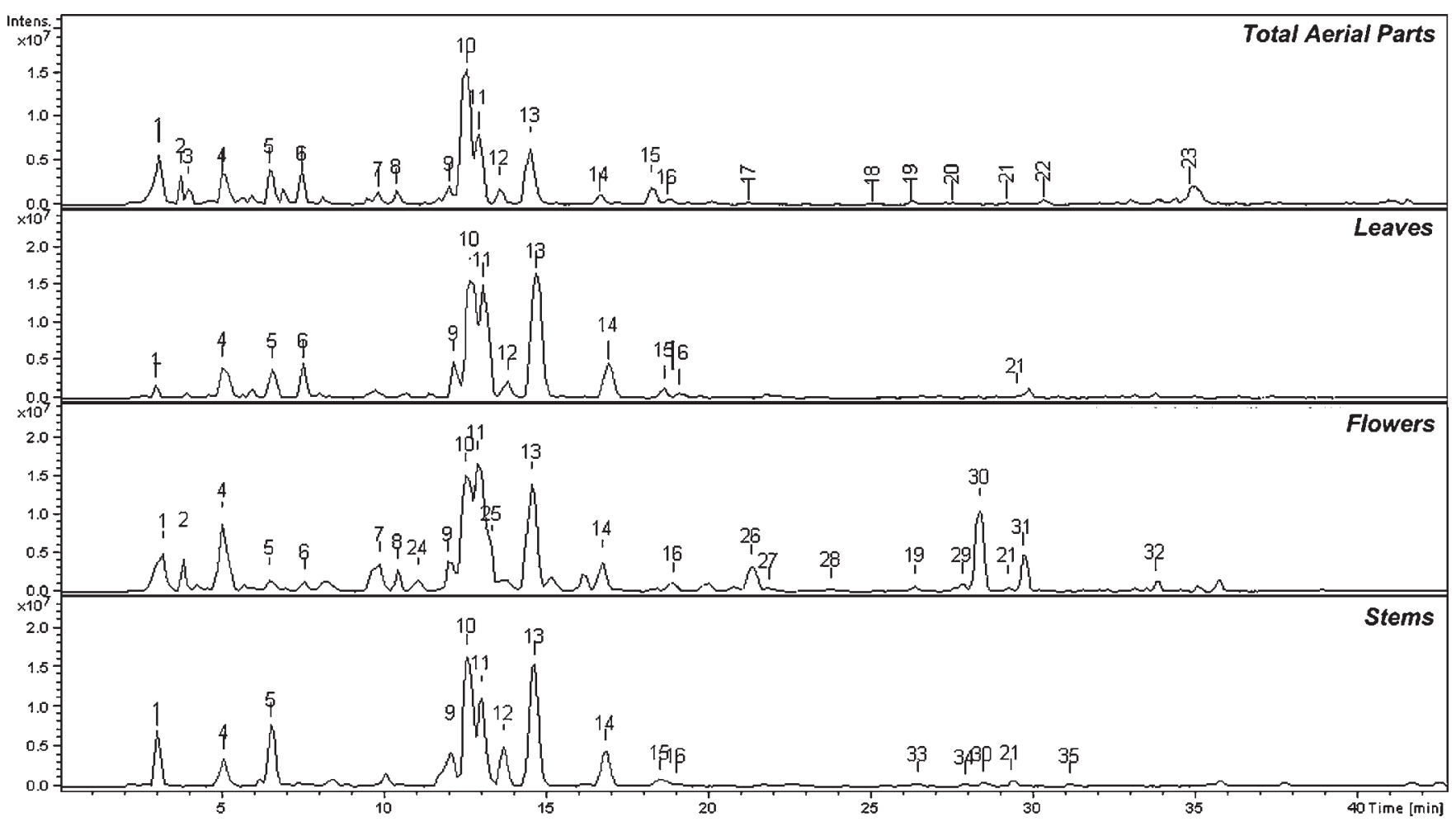

Figure 1. HPLC-DAD/ESI-MS ${ }^{n}$ analysis of the methanolic extracts of $H$. devium - LC/MS-negative ion ESI-MS base peak chromatogram (BPC). 
Table 1. Characterization of phenolic compounds of the methanolic extract of total aerial parts from Helichrysum devium by LCDAD/ESI-MS ${ }^{n}$

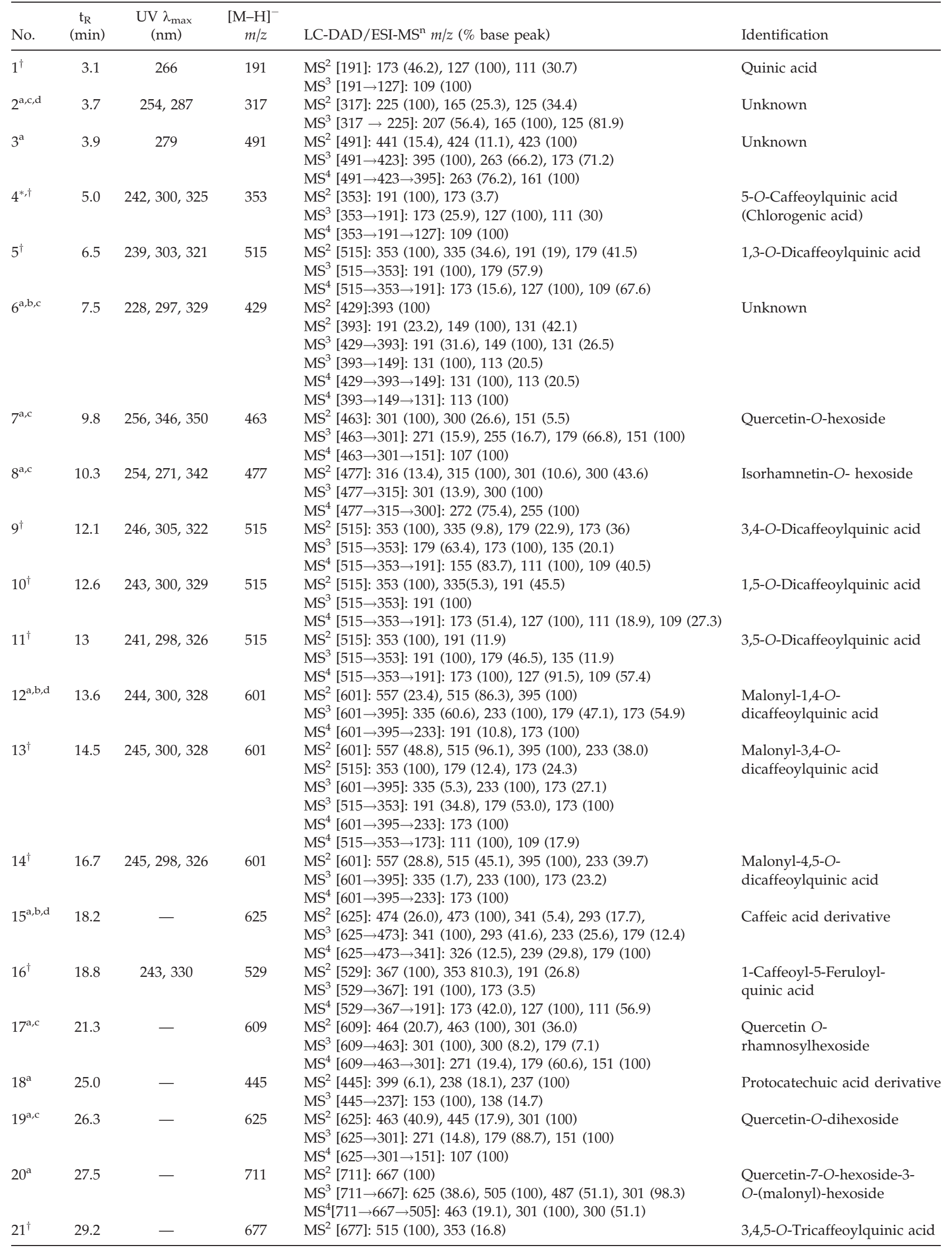


Table 1. (Continued)

\begin{tabular}{|c|c|c|c|c|c|}
\hline No. & $\begin{array}{c}t_{\mathrm{R}} \\
(\mathrm{min})\end{array}$ & $\begin{array}{l}\mathrm{UV} \lambda_{\max } \\
(\mathrm{nm})\end{array}$ & $\begin{array}{c}{[\mathrm{M}-\mathrm{H}]^{-}} \\
m / z\end{array}$ & LC-DAD/ESI-MS ${ }^{\mathrm{n}} \mathrm{m} / z$ ( $\%$ base peak) & Identification \\
\hline & & & & $\begin{array}{l}\text { MS }^{3}[677 \rightarrow 515]: 353(100), 179(35.1), 173(49.3) \\
\text { MS }^{4}[677 \rightarrow 515 \rightarrow 353]: 191(33.23), 179(65.9), 173 \text { (100) }\end{array}$ & \\
\hline $22^{\mathrm{a}}$ & 30.3 & - & 629 & $\begin{array}{l}\operatorname{MS}^{2}[629]: 475(41.4), 463(100) \\
\operatorname{MS}^{3}[629 \rightarrow 463]: 343(18.20), 301(54.2), 300(100) \\
\text { MS }^{4}[629 \rightarrow 463 \rightarrow 300]: 272(34.2), 271(100), 254(22.7), 151(44.6)\end{array}$ & Quercetin hexoside derivative \\
\hline $23^{\mathrm{a}}$ & 34.8 & - & 331 & $\begin{array}{l}\operatorname{MS}^{2}[331]: 155(100), 140(27.3), 125(35.5) \\
\text { MS }^{3}[331 \rightarrow 155]: 140(100), 125(9.1) \\
\text { MS }^{4}[331 \rightarrow 155 \rightarrow 140]: 125(100)\end{array}$ & Unknown \\
\hline
\end{tabular}

* Compared with standard compound.

${ }^{\dagger}$ Detected in all extracts.

${ }^{\text {a }}$ Detected in total aerial parts.

${ }^{\mathrm{b}}$ Detected in leaves.

${ }^{\mathrm{c}}$ Detected in flowers.

${ }^{\mathrm{d}}$ Detected in stems.

\section{Identification of hydroxycinnamic acid derivatives}

In this work several hydroxycinnamic acid derivatives were identified by LC-DAD/ESI-MS ${ }^{\mathrm{n}}$ experiments and their chemical structures and identification are presented in Fig. 2 and Table 5, respectively.

The deprotonated molecular ion $\left([\mathrm{M}-\mathrm{H}]^{-}\right)$was abundantly produced under the $\mathrm{MS}^{\mathrm{n}}$ conditions for all hydroxycinnamic acid derivatives and the loss of the substitution groups is always referred to in respect to this ion.

\section{Mono-, di- and tricaffeoylquinic acids}

\section{$(1,4,5,9,10,11,21)$}

Compound 1 occurred at a retention time of $3.1 \mathrm{~min}$ and exhibited a $[\mathrm{M}-\mathrm{H}]^{-}$ion at $\mathrm{m} / \mathrm{z}$ 191. Its $\mathrm{MS}^{2}$ fragmentation produced a $\left[\mathrm{M}-\mathrm{H}-\mathrm{CO}-2 \mathrm{H}_{2} \mathrm{O}\right]^{-}$ion at $m / z 127$ as base peak; a $\left[\mathrm{M}-\mathrm{H}-\mathrm{H}_{2} \mathrm{O}\right]^{-}$ion at $m / z 173$ was also observed. Compound $\mathbf{1}$ was identified as quinic acid, taking into account its $\mathrm{MS}^{\mathrm{n}}$ fragmentation pattern and literature data. ${ }^{13}$

It was reported previously ${ }^{14}$ that the linkage position of acyl groups on quinic acid could be determined by the analysis of the $[\mathrm{M}-\mathrm{H}]^{-}$ion $\mathrm{MS}^{2}$ fragmentation. In general, the [quinic acid-H] ${ }^{-}$ion at $\mathrm{m} / \mathrm{z} 191$ appears as the base peak when the acyl group is linked to the $3-\mathrm{OH}$ or $5-\mathrm{OH}$ position; these two isomers can be further differentiated since the [caffeic acid-H] ${ }^{-}$ion at $m / z 179$ is more significant for $3-\mathrm{OH}$ compounds. When the acyl group is connected to $4-\mathrm{OH}$, the [quinic acid- $\left.\mathrm{H}_{2} \mathrm{O}-\mathrm{H}\right]^{-}$ion at $\mathrm{m} / \mathrm{z} 173$ will appear as the base peak..$^{14,15}$

Identification of the detected quinic acid derivatives was performed based on these assumptions and by using the hierarchical key for the identification by $\mathrm{LC} / \mathrm{MS}^{\mathrm{n}}$ of caffeoylquinic and dicaffeoylquinic acids derivatives proposed by Clifford et al. ${ }^{16}$

Compound $4\left(t_{R}=5.0 \mathrm{~min}\right)$ was unequivocally identified as 5-O-caffeoylquinic acid (chlorogenic acid) by comparison of the retention time and mass spectra with those of a reference standard. This compound displayed a $[\mathrm{M}-\mathrm{H}]^{-}$ion at $m / z 353$, and its $\mathrm{MS}^{2}$ spectrum gave a [quinic acid-H] ${ }^{-}$ion at $\mathrm{m} / \mathrm{z} 191$ as the base peak and a [caffeic acid-H] ${ }^{-}$ion at $\mathrm{m} / \mathrm{z}$ 179 (weak ion, ca. 3\% of the base peak). The occurrence of 5-O-caffeoylquinic acid in plants of the Helichrysum genus is very common. ${ }^{2}$

In addition to the monocaffeoylquinic acid, several dicaffeoylquinic acid (diCQA) isomers and a tricaffeoylquinic acid (triCQA) were identified in Helichrysum devium.

Compounds 5, 9, 10 and 11 all gave molecular ions $[\mathrm{M}-\mathrm{H}]^{-}$ at $m / z 515$; their fragmentation in $\mathrm{MS}^{2}$ spectra gave, as the base peak, a $[\mathrm{M}-\mathrm{H}-162]^{-}$ion at $\mathrm{m} / \mathrm{z} 353$, indicating the presence of more than one caffeoyl group linked to different hydroxyl groups.

However, their MS ${ }^{3}$ and $\mathrm{MS}^{4}$ spectra of the $\mathrm{m} / \mathrm{z} 353$ ions were significantly different. The ion at $m / z 191$ was observed as the base peak for compound $\mathbf{5 , 1 0}$ and $\mathbf{1 1}$, but the ion at $\mathrm{m} / \mathrm{z}$ 173 was the base peak for compound 9 which, as mentioned above, indicates the presence of a $4-\mathrm{OH}$-substituted quinic acid.

According to the literature, ${ }^{15}$ it is possible to distinguish the 3,4-diCQA from the 4,5-diCQA since the two isomers differ in the intensity of the $\mathrm{MS}^{2}$ 'dehydrated' ion at $m / z 335$ $\left(\left[\mathrm{M}-\mathrm{H}_{2} \mathrm{O}-\mathrm{H}^{+}\right]^{-}\right)$. For 3,4-diCQA, the peak at $m / z 335$ is more intense ( $\sim 15 \%$ of base peak). In contrast, for 4,5 -diCQA this ion is barely detectable ( $<5 \%$ of base peak). The $\mathrm{MS}^{2}$ spectrum of compound 9 exhibited a secondary ion at $\mathrm{m} / z 335$ ( $13 \%$ of base peak), thus compound 9 was plausibly identified as 3,4-O-dicaffeoylquinic acid.

It has been reported that 3,4-O-dicaffeoylquinic acid is more easily eluted from the reversed-phase column when compared with 3,5-O-dicaffeoylquinic acid. Based on this information and comparing its $\mathrm{MS}^{\mathrm{n}}$ spectra and fragment intensities with the literature data, ${ }^{15}$ compound $\mathbf{1 1}$ was identified as 3,5-O-dicaffeoylquinic acid.

Compounds $\mathbf{5}$ and $\mathbf{1 0}$ were identified as 1,3-O-dicaffeoylquinic and 1,5-O-dicaffeoylquinic, respectively. Their $\mathrm{MS}^{3}$ spectra are quite different; compound 5 showed an ion at $\mathrm{m} / \mathrm{z}$ 179 ( 50\% of the base peak), characteristic of a 3-OHsubstituted quinic acid, ${ }^{3}$ as discussed before, and which is absent in the spectrum of compound 10. Moreover, as previously reported by Clifford et al., ${ }^{16}$ 1,3-diCQA eluted 
Table 2. Characterization of phenolic compounds of the methanolic extract of leaves from Helichrysum devium by LC-DAD/ESI$M S^{n}$

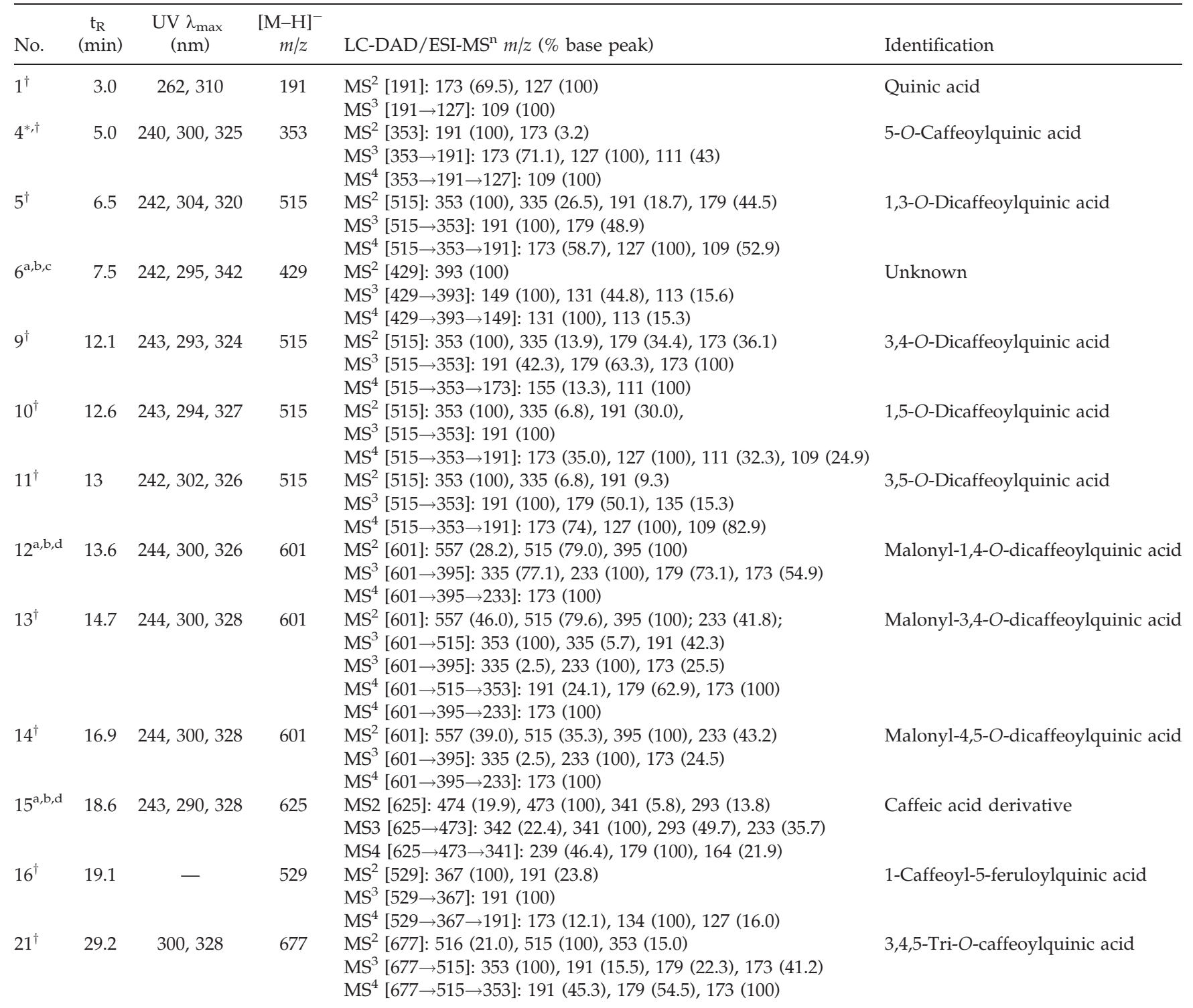

\footnotetext{
*Compared with standard compound.

${ }^{\dagger}$ Detected in all extracts.

${ }^{a}$ Detected in total aerial parts.

${ }^{\mathrm{b}}$ Detected in leaves.

${ }^{\mathrm{c}}$ Detected in flowers.

${ }^{\mathrm{d}}$ Detected in stems.
}

much earlier than 1,5-diCQA and these two isomers can also be distinguished by the relative intensity of the $\mathrm{MS}^{2}$ fragment at $\mathrm{m} / \mathrm{z} 335$ (1,3-diCQA, $\sim 30 \% ; 1,5$-diCQA, $\sim 7 \%$, and 3,5diCQA, not detectable).

Compound 21 appeared at a retention time $\left(t_{R}\right)$ of $29.2 \mathrm{~min}$ and displayed a $[\mathrm{M}-\mathrm{H}]^{-}$ion at $m / z$ 677, easily losing a caffeoyl moiety (162 Da) to form a base peak ion at $m / z 515$ in the $\mathrm{MS}^{2}$ spectrum. $\mathrm{MS}^{3}$ and $\mathrm{MS}^{4}$ spectra were identical with those described above for 3,4-diCQA (compound 9). So, it can be inferred that compound 21 is either 1,3,4-triCQA or 3,4,5triCQA. As, in general, CQAs with a larger number of free equatorial hydroxyl groups in the quinic acid residue are more hydrophilic than those with a larger number of free axial hydroxyl groups, ${ }^{16}$ the long retention time of this compound suggests a hydrophobic compound. Thus, compound 21 was identified as 3,4,5-triCQA.

All compounds mentioned above were found in all analyzed methanolic extracts.

\section{Malonylcaffeoylquinic acid $(12,13,14)$}

Compounds containing a malonyl group usually show characteristic ions $[\mathrm{M}-\mathrm{H}-44]^{-}$and $[\mathrm{M}-\mathrm{H}-86]^{-}$in the ESI negative mode of fragmentation. ${ }^{17}$

Compounds $12\left(t_{R}=13.6 \mathrm{~min}\right), 13\left(t_{R}=14.5 \mathrm{~min}\right)$ and 14 $\left(t_{\mathrm{R}}=16.7 \mathrm{~min}\right)$ showed a $[\mathrm{M}-\mathrm{H}]^{-}$ion at $\mathrm{m} / \mathrm{z} 601$ and their $\mathrm{MS}^{2}$ spectra gave ions $[\mathrm{M}-\mathrm{H}-44]^{-}$at $m / z 557$ and $[\mathrm{M}-\mathrm{H}-86]^{-}$at 
Table 3. Characterization of phenolic compounds of the methanolic extract of flowers from Helichrysum devium by LC-DAD/ESI$\mathrm{MS}^{\mathrm{n}}$

\begin{tabular}{|c|c|c|c|c|c|}
\hline No. & $\begin{array}{c}t_{\mathrm{R}} \\
(\mathrm{min})\end{array}$ & $\begin{array}{l}\mathrm{UV} \lambda_{\max } \\
(\mathrm{nm})\end{array}$ & $\begin{array}{c}{[\mathrm{M}-\mathrm{H}]^{-}} \\
m / z\end{array}$ & LC-DAD/ESI-MS ${ }^{\mathrm{n}} m / z$ ( $\%$ base peak) & Identification \\
\hline $1^{\dagger}$ & 2.9 & 261 & 191 & $\begin{array}{l}\mathrm{MS}^{2} \text { [191]: } 173(74), 127(100), 111 \text { (33.3) } \\
\text { MS }^{3}[191 \rightarrow 127]: 109(100)\end{array}$ & Quinic acid \\
\hline $2^{a, c}$ & 3.7 & 232,319 & 317 & $\begin{array}{l}\mathrm{MS}^{2} \text { [317]: } 225(100), 165(33.0), 125(17.1) \\
\left.\text { MS }^{3} \text { [317 } \rightarrow 225\right]: 207(100), 125(96.5), 165 \text { (85.5) }\end{array}$ & Unknown \\
\hline $4^{*, \dagger}$ & 5.0 & $241,300,325$ & 353 & $\begin{array}{l}\operatorname{MS}^{2}[353]: 191(100), 173(3.7) \\
\text { MS }^{3}[353 \rightarrow 191]: 173(25.9), 127(100), 111(30) \\
\text { MS }^{4}[353 \rightarrow 191 \rightarrow 127]: 109(100)\end{array}$ & $\begin{array}{l}\text { 5-O-Caffeoylquinic acid } \\
\text { (Chlorogenic acid) }\end{array}$ \\
\hline $5^{\dagger}$ & 6.5 & $244,297,321$ & 515 & $\begin{array}{l}\operatorname{MS}^{2}[515]: 353(100), 335(23.3), 191(29.37), 179(43.6) \\
\text { MS }^{3}[515 \rightarrow 353]: 191(100), 179(48.0) \\
\text { MS }^{4}[515 \rightarrow 353 \rightarrow 191]: 173(100), 127(46.9)\end{array}$ & 1,3-O-Dicaffeoylquinic acid \\
\hline $6^{a, b, c}$ & 7.5 & $244,280,324$ & 429 & $\begin{array}{l}\operatorname{MS}^{2}[429]: 393(100) \\
\text { MS }^{2}[393]: 191(18.3), 149(100), 131(35.9) \\
\text { MS }^{3}[429 \rightarrow 393]: 251(24.5), 191(15.8), 149(100), 131(44.4) \\
\text { MS }^{3}[393 \rightarrow 149]: 131(100), 113(52.1) \\
\text { MS }^{4}[429 \rightarrow 393 \rightarrow 149]: 131(100), 119(41.7) \\
\text { MS }^{4}[393 \rightarrow 149 \rightarrow 131]: 113(100)\end{array}$ & Unknown \\
\hline $7^{\mathrm{a}, \mathrm{c}}$ & 9.9 & 255,352 & 463 & $\begin{array}{l}\operatorname{MS}^{2} \text { [463]: } 301(100), 300(20.9), 151(6.2) \\
\operatorname{MS}^{3} \text { [301]: } 271(19.6), 255(18.6), 179(100), 151(84.4) \\
\operatorname{MS}^{4}[179]: 151(100), 107(7.3)\end{array}$ & Quercetin-O-hexoside \\
\hline $8^{a, c}$ & 10.4 & 255,342 & 477 & $\begin{array}{l}\mathrm{MS}^{2}[477]: 316(11.6), 315(100), 300(42.0) \\
\text { MS }^{3}[477 \rightarrow 315]: 301(15.8), 300(100) \\
\text { MS }^{4}[477 \rightarrow 315 \rightarrow 300]: 272(52.9) \\
271(59.8), 255(51.6), 216(100)\end{array}$ & Isorhamnetin-O-hexoside \\
\hline $24^{c}$ & 11.0 & $209,257,343$ & 461 & $\begin{array}{l}\text { MS2 [461]: } 286(17.6), 285(100) \\
\text { MS3 [461 } \rightarrow 285]: 257(5.8), 243(70.5), 241(52.7) \\
217(93.1), 199(99.9), 175(100), 151(28.1)\end{array}$ & Luteolin-7-O-glucuronide \\
\hline $6^{\dagger}$ & 12.1 & $243,302,327$ & 515 & $\begin{array}{l}\mathrm{MS}^{2}[515]: 353(100), 335(12.9), 179(22.2), 173(53.4) \\
\text { MS }^{3}[515 \rightarrow 353]: 191(22.9), 179(65.9), 173(100) \\
\text { MS }^{4}[515 \rightarrow 353 \rightarrow 173]: 155(47.1), 111(100), 109(35.8)\end{array}$ & 3,4-O-Dicaffeoylquinic acid \\
\hline $7^{\dagger}$ & 12.6 & $243,300,328$ & 515 & $\begin{array}{l}\operatorname{MS}^{2}[515]: 353(100), 191(54.6) \\
\operatorname{MS}^{3}[515 \rightarrow 353]: 191(100) \\
\operatorname{MS}^{4}[515 \rightarrow 353 \rightarrow 191]: 173(25.1) \\
127(100), 111(37.1), 109(16.4)\end{array}$ & 1,5-O-Dicaffeoylquinic acid \\
\hline $8^{\dagger}$ & 13 & $242,300,328$ & 515 & $\begin{array}{l}\text { MS }^{2}[515]: 353(100), 191(9.6) \\
\text { MS }^{3}[515 \rightarrow 353]: 191(100), 179(46.2), 135(15.6) \\
\text { MS }^{4}[515 \rightarrow 353 \rightarrow 191]: 173(57.7), 127(100), 111(72)\end{array}$ & 3,5-O-Dicaffeoylquinic acid \\
\hline $25^{*, \mathrm{c}}$ & 13.2 & 286,332 & 431 & $\begin{array}{l}\mathrm{MS}^{2}[431]: 270(15.6), 269(100) \\
\operatorname{MS}^{3}[431 \rightarrow 269]: 225(83.9), 224(55.8) \\
181(62.3), 149(29.5), 117(100) \\
\operatorname{MS}^{4}[431 \rightarrow 269 \rightarrow 224]: 197(100), 195(53.8)\end{array}$ & Apigenin-7-O-glucoside \\
\hline $13^{\dagger}$ & 14.5 & $244,300,327$ & 601 & $\begin{array}{l}\mathrm{MS}^{2}[601]: 557(42.1), 515(95.7), 395(100), 233(30.4) \\
\text { MS }^{3}[601 \rightarrow 395]: 335(5.2), 233(100), 173(19.7) \\
\text { MS }^{4}[601 \rightarrow 395 \rightarrow 233]: 173(100)\end{array}$ & Malonyl-3,4-di-O-caffeoylquinic acid \\
\hline $14^{\dagger}$ & 16.9 & $244,300,328$ & 601 & $\begin{array}{l}\text { MS }^{2} \text { [601]: } 557(29.6), 515(37.4), 395(100), 233(45.94) \\
\text { MS }^{3}[601 \rightarrow 395]: 335(3.4), 233(100), 173(33.2) \\
\text { MS }^{4}[601 \rightarrow 395 \rightarrow 233]: 173(100)\end{array}$ & Malonyl-4,5-di-O-caffeoylquinic acid \\
\hline $16^{\dagger}$ & 18.8 & $234,291,328$ & 529 & $\begin{array}{l}\operatorname{MS}^{2}[529]: 367(100), 353(19.4), 191(19.4) \\
\text { MS }^{3}[529 \rightarrow 367]: 191(100), 173(6.2) \\
\text { MS }^{4}[529 \rightarrow 367 \rightarrow 191]: 173(80.4), 127(100)\end{array}$ & 1-Caffeoyl-5-feruloylquinic acid \\
\hline $17^{\mathrm{a}, \mathrm{c}}$ & 21.3 & 265,314 & 609 & $\begin{array}{l}\operatorname{MS}^{2}[609]: 464(18.3), 463(100), 301(28.9) \\
\operatorname{MS}^{3}[609 \rightarrow 463]: 301(100), 300(30.0) \\
\operatorname{MS}^{4}[609 \rightarrow 463 \rightarrow 301]: 271(31.6) \\
255(18.5), 179(82), 151(100)\end{array}$ & Quercetin O-rhamnosylhexoside \\
\hline $26^{c}$ & 21.9 & - & 529 & $\begin{array}{l}\mathrm{MS}^{2} \text { [529]: } 368(13.0), 367(100), 161(13.0) \\
\mathrm{MS}^{3}[529 \rightarrow 367]: 191(27.4) \\
179(100), 161(84.8), 135(72.4) \\
\mathrm{MS}^{4}[529 \rightarrow 367 \rightarrow 179]: 135(100)\end{array}$ & Caffeic acid derivative \\
\hline $27^{c}$ & 23.7 & - & 609 & $\begin{array}{l}\mathrm{MS}^{2} \text { [609]: } 464(17.9), 463(100), 301(28.6) \\
\mathrm{MS}^{3}[609 \rightarrow 463]: 301(100), 300(24.1) \\
\text { MS }^{4}[609 \rightarrow 463 \rightarrow 301]: 271(24.2) \\
255 \text { (15.4), } 179(100), 151(69)\end{array}$ & Quercetin $O$-coumaroylhexoside \\
\hline $19^{\mathrm{a}, \mathrm{c}}$ & 26.3 & - & 625 & $\begin{array}{l}\mathrm{MS}^{2} \text { [625]: } 463(41.3), 445(22.8), 301(100) \\
\mathrm{MS}^{3}[625 \rightarrow 301]: 273(14.7), 271(17.7) \\
257(8.4), 255(12.3), 179(100), 151(95.6)\end{array}$ & Quercetin dihexoside \\
\hline
\end{tabular}


Table 3. (Continued)

\begin{tabular}{|c|c|c|c|c|c|}
\hline No. & $\begin{array}{c}\mathrm{t}_{\mathrm{R}} \\
(\mathrm{min})\end{array}$ & $\begin{array}{l}\mathrm{UV} \lambda_{\max } \\
(\mathrm{nm})\end{array}$ & $\begin{array}{c}{[\mathrm{M}-\mathrm{H}]^{-}} \\
\mathrm{m} / \mathrm{z}\end{array}$ & LC-DAD/ESI-MS ${ }^{\mathrm{n}} \mathrm{m} / z$ (\% base peak) & Identification \\
\hline $28^{*, \mathrm{c}}$ & 27.7 & - & 285 & $\begin{array}{l}\operatorname{MS}^{4}[625 \rightarrow 301 \rightarrow 179]: 151(100), 107(16.3) \\
\operatorname{MS}^{2}[285]: 243(46.4), 241(83.9), 217(26.5), \\
199(72.1), 175(100), 151(29.2), 135(4.2) \\
\operatorname{MS}^{3}[285 \rightarrow 175]: 147(100)\end{array}$ & Luteolin \\
\hline $29^{c, d}$ & 28.3 & 266,313 & 593 & $\begin{array}{l}\mathrm{MS}^{2} \text { [593]: } 447(9.8), 307(10.0), 285(100) \\
\left.\left.\mathrm{MS}^{3} \text { [593 } 285\right]: 257850.2\right), 255(50.9) \\
229 \text { (45.8), } 167(52 .), 151(100) \\
\text { MS }^{4} \text { [151]: } 107(100)\end{array}$ & Kaempferol-O-coumaroylhexoside \\
\hline $21^{\dagger}$ & 29.2 & - & 677 & $\begin{array}{l}\mathrm{MS}^{2}[677]: 515(100), 353(17.8) \\
\mathrm{MS}^{3}[677 \rightarrow 515]: 353(100), 335(13.5) \\
191(15.6), 179(25.0), 173(32.1) \\
\text { MS }^{4}[677 \rightarrow 515 \rightarrow 353]: 191(45.3) \\
179(54.5), 173(100)\end{array}$ & $3,4,5-O-$ Tricaffeoylquinic acid \\
\hline $30^{c}$ & 29.7 & 266,311 & 593 & $\begin{array}{l}\mathrm{MS}^{2} \text { [593]: } 447(8.4), 307(4.2), 285(100) \\
\mathrm{MS}^{3}[593 \rightarrow 285]: 257(52.5) \\
255 \text { (22.3), } 229(13.6), 151(100) \\
\text { MS }^{4}[151]: 107(100)\end{array}$ & Kaempferol-O-coumaroylhexoside \\
\hline $31^{*, \mathrm{c}}$ & 33.7 & 267,332 & 269 & $\begin{array}{l}\operatorname{MS}^{2} \text { [269]: } 227(25.4), 225(100) \\
201(39.9), 151(42.5), 149(74.1) \\
\operatorname{MS}^{3}[269 \rightarrow 225]: 198(36.1), 183(75.7), 181(100)\end{array}$ & Apigenin \\
\hline
\end{tabular}

*Compared with standard compound.

${ }^{\dagger}$ Detected in all extracts.

${ }^{\text {a }}$ Detected in total aerial parts.

${ }^{\mathrm{b}}$ Detected in leaves.

${ }^{\mathrm{c}}$ Detected in flowers.

${ }^{\mathrm{d}}$ Detected in stems.

$m / z 515$, indicating the presence of a malonyl residue in their structures.

For all compounds, the $\mathrm{MS}^{2}$ fragmentation of the deprotonated molecular ion led to the formation of an ion at $\mathrm{m} / \mathrm{z} 395$ (base peak) due to the loss of 206 Da (acetyl caffeoyl). Based on the occurrence of this fragment, it is possible to deduce that the malonyl group is attached to one caffeoyl group instead of being linked to the quinic acid structure. To our knowledge, this is the first time that this linkage is described for malonylcaffeoylquinic acid derivatives.

The base peak in all the $\mathrm{MS}^{3}$ spectra was a [M-H-44-162$162]^{-}$ion at $m / z 233$ assigned to acetylquinic acid, as previously described by Zhang et al. ${ }^{17}$ This acetylation can stabilize the ring structure of quinic acid, which was confirmed by the non-observation of ions corresponding to ring fragmentation.

The malonyl group should be attached to the caffeoyl group at the $3-\mathrm{OH}$ position of the quinic acid structures. This evidence is supported by fragmentation of the ion at $m / z 395$, where a fragment at $m / z 173(\sim 25 \%)$ is observed. This ion is due to the loss of a caffeoyl group linked to the $4-\mathrm{OH}$ position.

For compound $13, \mathrm{MS}^{2}$ fragmentation of the $[\mathrm{M}-\mathrm{H}-86]^{-}$ ion resulted in the identification of a 3,4-diCQA moiety, by comparison with the fragmentation of compound 9 (Fig. 3, Scheme 1).

As already mentioned, compounds $\mathbf{1 2}$ and $\mathbf{1 4}$ showed a similar fragmentation pattern when compared to compound 13 , but it was not possible to fragment the $[\mathrm{M}-\mathrm{H}-86]^{-}$ion in order to establish the exact position where the caffeoyl moieties are attached. However, the occurrence of an ion at $m / z 173$ as the base peak in the $\mathrm{MS}^{4}$ spectrum indicates the presence of a 4-OH linkage position in the quinic acid structure.
According to the rules for diCQA, ${ }^{15}$ it was assumed that malonylcaffeoylquinic acid isomers have the same order of elution. So, accepting that 3,4-diCQA is more easily eluted from the reversed-phase column than 4,5-diCQA, compounds 12, 13 and 14 were identified as malonyl-1,4-Odicaffeoylquinic acid, malonyl-3,4-O-dicaffeoylquinic acid and malonyl-4,5-O-dicaffeoylquinic acid, respectively. These three compounds were detected in all extracts, with the exception of compound $\mathbf{1 2}$ which was not detected in the flowers extract.

\section{Caffeoylferuloylquinic acid $(16,26)$}

It was possible to identify two feruloylquinic acid derivatives (compound 16 and 26) in the four analyzed extracts. Compound 16 was detected for all extracts but compound 26 could only be detected in the flowers extract; both exhibited a $[\mathrm{M}-\mathrm{H}]^{-}$ion at $m / z 529$.

$\mathrm{MS}^{\mathrm{n}}$ fragmentation of compound $16\left(\mathrm{t}_{\mathrm{R}}=18.9 \mathrm{~min}\right)$ gave $\mathrm{MS}^{2}$ and $\mathrm{MS}^{3}$ base peaks at $m / z 367$ [feruloylquinic acid-H] ${ }^{-}$ and $m / z 191$ [quinic acid-H] $^{-}$, respectively. Based on these fragments, this compound was characterized as a caffeoylferuoylquinic acid (CFQA) isomer.

Identification of compound $\mathbf{1 6}$ was tentatively made by referring to the hierarchical key developed by Clifford et al. ${ }^{15}$ Since the $\mathrm{MS}^{3}$ spectrum displayed an ion at $\mathrm{m} / \mathrm{z} 191$ as the base peak, this compound should be a $3-\mathrm{OH}-$ or $5-\mathrm{OH}-$ substituted quinic acid. If it was a $3-\mathrm{OH}$-substituted compound, the peak abundance at $m / z 179$ should be above $50 \%$ of the base peak, which it is not observed in this case, so compound 16 was plausibly identified as 1-O-caffeoyl-5-Oferuoylquinic acid.

Compound $26\left(t_{R}=21.9 \mathrm{~min}\right)$ yielded a different fragmentation behaviour when compared with compound 16. The 
Table 4. Characterization of phenolic compounds of the methanolic extract of the stems from Helichrysum devium by LC-DAD/ ESI-MS ${ }^{\mathrm{n}}$

\begin{tabular}{|c|c|c|c|c|c|}
\hline No. & $\begin{array}{c}t_{R} \\
(\min )\end{array}$ & $\begin{array}{l}\mathrm{UV} \lambda_{\max } \\
(\mathrm{nm})\end{array}$ & $\begin{array}{c}{[\mathrm{M}-\mathrm{H}]^{-}} \\
m / z\end{array}$ & LC-DAD/ESI-MS ${ }^{\mathrm{n}} m / z$ ( $\%$ base peak) & Identification \\
\hline $1^{\dagger}$ & 3.1 & 261 & 191 & $\begin{array}{l}\mathrm{MS}^{2}[191]: 173(100), 127(74), 111(52.5) \\
\mathrm{MS}^{3}[191 \rightarrow 173]: 125(82.6), 109(100)\end{array}$ & Quinic acid \\
\hline $4^{*, \dagger}$ & 5.0 & $243,300,325$ & 353 & $\begin{array}{l}\operatorname{MS}^{2}[353]: 191(100), 179(3.9) \\
\text { MS }^{3}[353 \rightarrow 191]: 173(61.8), 127(78.7), 111(100) \\
\text { MS }^{4}[353 \rightarrow 191 \rightarrow 111]: 109(100)\end{array}$ & $\begin{array}{l}\text { 5-O-Caffeoylquinic acid } \\
\text { (Chlorogenic acid) }\end{array}$ \\
\hline $5^{\dagger}$ & 6.5 & $243,303,321$ & 515 & $\begin{array}{l}\operatorname{MS}^{2}[515]: 353(100), 335(25.0), 191(24.7), 179(47.3) \\
\text { MS }^{3}[515 \rightarrow 353]: 191(100), 179(41.8), 135(10.8) \\
\text { MS }^{4}[515 \rightarrow 353 \rightarrow 191]: 173(100), 127(68.4), 111(31.5)\end{array}$ & 1,3-O-Dicaffeoylquinic acid \\
\hline $9^{\dagger}$ & 12.0 & $243,301,325$ & 515 & $\begin{array}{l}\operatorname{MS}^{2}[515]: 353(100), 335(9.8), 179(26.6), 173(44.8) \\
\text { MS }^{3}[515 \rightarrow 353]: 191(38.9), 179(71.3), 173(100), 135(16.2) \\
\text { MS }^{4}[515 \rightarrow 353 \rightarrow 173]: 155(47.1), 111(100)\end{array}$ & 3,4-O-Dicaffeoylquinic acid \\
\hline $10^{\dagger}$ & 12.6 & $243,302,327$ & 515 & $\begin{array}{l}\operatorname{MS}^{2}[515]: 353(100), 335(6.5), 191(38.5) \\
\text { MS }^{3}[515 \rightarrow 353]: 191(100) \\
\text { MS }^{4}[515 \rightarrow 353 \rightarrow 191]: 173(29.1), 127(100), 109(40.2)\end{array}$ & 1,5-O-Dicaffeoylquinic acid \\
\hline $11^{\dagger}$ & 13 & $242,298,326$ & 515 & $\begin{array}{l}\operatorname{MS}^{2}[515]: 353(100), 335(1.3) \\
\text { MS }^{3}[515 \rightarrow 353]: 191(100), 179(43.8) \\
\text { MS }^{4}[515 \rightarrow 353 \rightarrow 191]: 173(100), 127(55.2), 109(28.1)\end{array}$ & 3,5-O-Dicaffeoylquinic acid \\
\hline $12^{\mathrm{a}, \mathrm{b}, \mathrm{d}}$ & 13.6 & $244,300,329$ & 601 & $\begin{array}{l}\text { MS }^{2}[601]: 557(23.0), 515(100), 395(96.1) \\
\text { MS }^{3}[601 \rightarrow 515]: 353(100), 299(22.6), 203(42.2) \\
\text { MS }^{4}[601 \rightarrow 515 \rightarrow 353]: 191(18), 179(47.3), 173(100)\end{array}$ & Malonyl-1,4-O-dicaffeoylquinic acid \\
\hline $13^{\dagger}$ & 14.5 & $245,302,328$ & 601 & $\begin{array}{l}\operatorname{MS}^{2} \text { [601]: } 557(52.8), 515(74.1), 395(100), 233(34.2) \\
\text { MS }^{3}[601 \rightarrow 395]: 335(3.6), 233(100), 173(19.8) \\
\text { MS }^{4}[601 \rightarrow 395 \rightarrow 233]: 173(100)\end{array}$ & Malonyl-3,4-O-dicaffeoylquinic acid \\
\hline $14^{\dagger}$ & 16.9 & $244,300,328$ & 601 & $\begin{array}{l}\text { MS }^{2}[601]: 557(27.9), 515(37.2), 395(100), 233(43.2) \\
\text { MS }^{3}[601 \rightarrow 395]: 335(2.6), 233(100), 173(27.1) \\
\text { MS }^{4}[601 \rightarrow 395 \rightarrow 233]: 173(100)\end{array}$ & Malonyl-4,5-O-dicaffeoylquinic acid \\
\hline $15^{\mathrm{a}, \mathrm{b}, \mathrm{d}}$ & 18.4 & 261,352 & 625 & $\begin{array}{l}\mathrm{MS}^{2} \text { [625]: } 474(17.1), 473(100), 341(8.7), 293(13.0) \\
\left.\mathrm{MS}^{3} \text { [625 } \rightarrow 473\right]: 341(100), \\
293 \text { (56.7), } 233(34.3), 179(24.1) \\
\mathrm{MS}^{4}[625 \rightarrow 473 \rightarrow 341]: 239(287.99 .8), 179(100), 164(32)\end{array}$ & Caffeic acid derivative \\
\hline $16^{\dagger}$ & 19.0 & - & 529 & $\begin{array}{l}\mathrm{MS}^{2} \text { [529]: } 368(12.4), 367(100), 353(13.2), 191(18.2) \\
\mathrm{MS}^{3}[529 \rightarrow 367]: 193(14.6), 191(100) \\
\text { MS }^{4}[529 \rightarrow 367 \rightarrow 191]: 173(12.0) \\
134(100), 127(36.3), 111(22.8)\end{array}$ & 1-Caffeoyl-5-feruloylquinic acid \\
\hline $32^{\mathrm{d}}$ & 26.4 & - & 583 & $\begin{array}{l}\operatorname{MS}^{2}[583]: 422(24.9), 421(100), 335(8.8), 259(69.2), \\
\text { MS }^{3}[583 \rightarrow 421]: 259(100), 173(29.7) \\
\text { MS }^{4}[583 \rightarrow 421 \rightarrow 259]: 173(100), 155 \text { (9.9) }\end{array}$ & Unknown \\
\hline $33^{\mathrm{d}}$ & 27.9 & - & 583 & $\begin{array}{l}\text { MS }^{2}[583]: 422(23.2), 421(100), 299(26.9), 255(19.4) \\
\text { MS }^{3}[583 \rightarrow 421]: 353(100), 335(74.5) \\
259(72.5), 179(43.2), 173(53.6) \\
\text { MS }^{4}[583 \rightarrow 421 \rightarrow 353]: 179(100), 173(95.7), 135(50.0)\end{array}$ & Caffeic acid derivative \\
\hline $29^{c, d}$ & 28.3 & - & 593 & $\begin{array}{l}\operatorname{MS}^{2}[593]: 447(8.4), 307(4.0), 285(100) \\
\text { MS }^{3}[593 \rightarrow 285]: 257(68.9), 255(24.6), 151(100) \\
\text { MS }^{4}[151]: 107(100)\end{array}$ & Kaempferol-O-coumaroylglucoside \\
\hline $21^{\dagger}$ & 29.2 & $242,300,325$ & 677 & $\begin{array}{l}\mathrm{MS}^{2} \text { [677]: } 515(100), 353(18.2) \\
\left.\text { MS }^{3} \text { [677 } \rightarrow 515\right]: 353(100), 179(21.0), 173(37.6) \\
\text { MS }^{4}[677 \rightarrow 515 \rightarrow 353]: 191(38.4), 179(63.8), 173(100)\end{array}$ & 3,4,5-O-Tricaffeoylquinic acid \\
\hline $34^{\mathrm{d}}$ & 31.1 & - & 567 & $\begin{array}{l}\operatorname{MS}^{2}[567]: 323(100), 179(28.1), 161(19.9) \\
\text { MS }^{3}[567 \rightarrow 323]: 179(93.3), 161(100), 135(36.0) \\
\text { MS }^{4}[567 \rightarrow 323 \rightarrow 161]: 133(100)\end{array}$ & Unknown \\
\hline
\end{tabular}

${ }^{*}$ Compared with standard compound.

${ }^{\dagger}$ Detected in all extracts.

${ }^{\text {a }}$ Detected in total aerial parts.

${ }^{\mathrm{b}}$ Detected in leaves.

${ }^{\mathrm{c}}$ Detected in flowers.

${ }^{\mathrm{d}}$ Detected in stems.

$\mathrm{MS}^{2}$ spectrum gave an ion at $m / z 367$, indicating the presence of a feruoylquinic acid residue but, in the further $\mathrm{MS}^{\mathrm{n}}$ experiments, the presence of ferulic acid could not be confirmed. In the $\mathrm{MS}^{3}$ spectrum, the base peak is the [caffeoyl-H] $]^{-}$ion at $m / z 179$. For these reasons, and with no further information, compound $\mathbf{2 6}$ could only be characterized as a caffeic acid derivative.
Identification of flavonoids compounds $(7,8,17$, $19,20,22,24,25,27,28,29$, and 30)

The present work led to the identification and characterization of a number of flavonoids with aglycones belonging to two subtypes: flavonols (quercetin, isorhamnetin and kaempferol) and flavones (luteolin and apigenin) (Fig. 2). Nearly all flavonoids were identified as glycosides contain- 
<smiles>COC(=O)CC(=O)O</smiles>

Malonyl<smiles>O=C(O)C1(O)CCCCCCCC1[18O]</smiles>

Quinic acid<smiles>O=C(O)C1OC(O)C(O)C(O)C1O</smiles>

Glucuronide

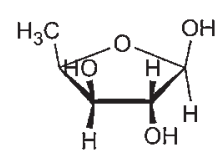

Rhamnosyl<smiles>[R]Cc1ccc2c(=O)c(O)c(-c3ccc([R])c([R3])c3)oc2c1</smiles>

Flavonol type

\begin{tabular}{c|c|c|c|c}
\hline Flavonol type & $\mathrm{R}_{1}$ & $\mathrm{R}_{2}$ & $\mathrm{R}_{3}$ & $\mathrm{R}_{4}$ \\
\hline Quercetin & $\mathrm{OH}$ & $\mathrm{OH}$ & $\mathrm{OH}$ & $\mathrm{OH}$ \\
\hline Kaempferol & $\mathrm{OH}$ & $\mathrm{OH}$ & $\mathrm{H}$ & $\mathrm{OH}$ \\
\hline Isorhamnetin & $\mathrm{OH}$ & $\mathrm{OH}$ & $\mathrm{OCH}_{3}$ & $\mathrm{OH}$ \\
\hline
\end{tabular}<smiles>OC[C@H](O)[C@H]1O[C@H](O)[C@@H](O)[C@H]1O</smiles>

Coumaroyl $\mathrm{R}=\mathrm{H}$ Caffeoyl $\mathrm{OH}$ Feruoyl $\quad \mathrm{OCH}_{3}$

Figure 2. Chemical structures of flavonoid aglycones and substitution groups identified in methanolic extracts from Helichrysum devium.

ing one or more sugar moieties and some were esterified with acyl groups. The $\mathrm{MS}^{\mathrm{n}}$ fragmentation of these phenolic compounds showed the deprotonated molecular ion ([M$\mathrm{H}^{-}$) and the deprotonated aglycone ion $\left(\mathrm{Y}_{0}^{-}\right)$as a result of the loss of the sugar residue. The presence of hexoside, rhamnose, malonyl and glucunoride moieties was characterized by neutral losses of 162, 146, 146 and $176 \mathrm{Da}$, respectively. The flavonoid fragment ions were designated according to the nomenclature proposed by Ma et al. ${ }^{18}$ (Fig. 4). For free aglycones, the ${ }^{\mathrm{i}, j} \mathrm{~A}^{-}$and ${ }^{\mathrm{i}, \mathrm{j}} \mathrm{B}^{-}$labels correspond to ions containing intact $\mathrm{A}$ - and B-rings, respectively, in which $\mathrm{i}$ and $\mathrm{j}$ indicate the $\mathrm{C}$-ring bonds that have been broken (Fig. 4). For conjugated aglycones, $\mathrm{Y}_{0}^{-}$ is used to refer to the aglycone fragment $\left[\mathrm{M}-\mathrm{H}-\right.$ glycoside $^{-}$.

Most of the identified flavonoids were exclusively detected in the flowers extract $(7,8,17,19,24,25,27,28,29$, and 30); compounds 7, 8, 17 and 19 were also detected in the total plant extract and compound $\mathbf{2 9}$ in the stems. Compounds $\mathbf{2 0}$ and 22 were only detected in the total plant extract.

Compound $7\left(t_{\mathrm{R}}=9.8 \mathrm{~min}\right)$ yielded a $[\mathrm{M}-\mathrm{H}]^{-}$ion at $m / z 463$ and its analysis by $\mathrm{MS}^{2}$ resulted in the aglycone fragment $\left(\mathrm{Y}_{0}^{-}\right)$at $\mathrm{m} / \mathrm{z} 301$ (loss of $162 \mathrm{Da}$, probably due to an hexoside residue). The $\mathrm{MS}^{\mathrm{n}}$ fragmentation gave ions at $\mathrm{m} / \mathrm{z} 151$ $\left({ }^{1,2} \mathrm{~A}^{-}-\mathrm{CO}\right), 179\left(\left[^{1,2} \mathrm{~A}^{-}-\mathrm{H}\right]^{-}\right), 255\left(\left[\mathrm{M}-\mathrm{H}-\mathrm{H}_{2} \mathrm{O}-\mathrm{CO}\right]^{-}\right)$and

Table 5. Quinic acid derivatives identified by LC/ESI-MS ${ }^{n}$ in different morphological parts of Helichrysum devium

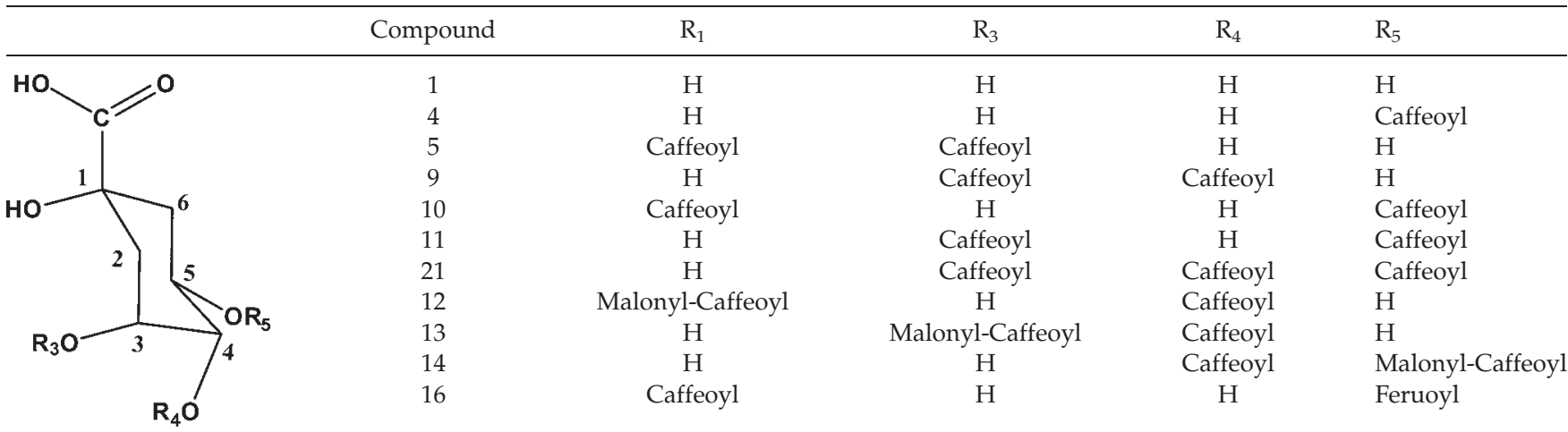

Quinic acid 
(a)

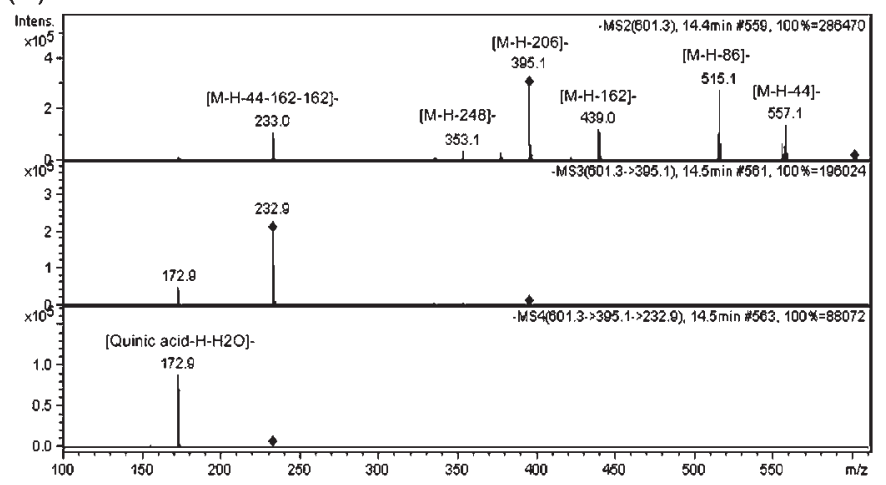

(b)

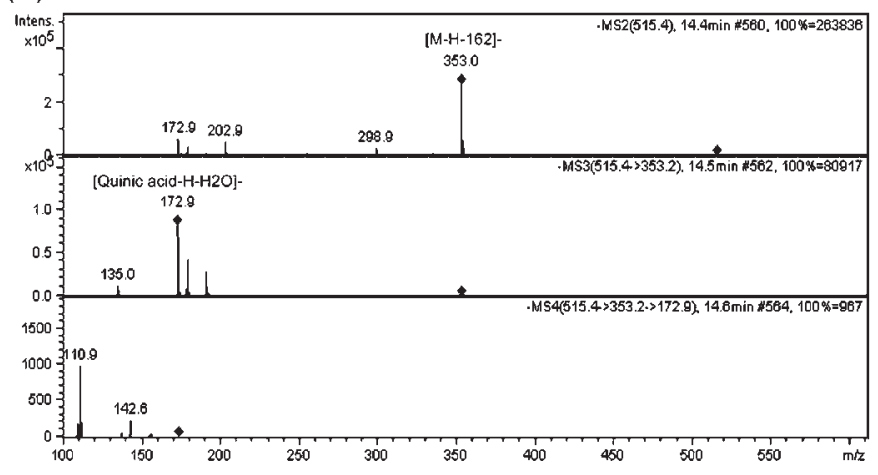

Figure 3. ESI-MS ${ }^{n}$ negative mode of compound 13. Sequential fragmentation, $M^{n}(n=2-4)$, of (a) the ion at $m / z 601$ and (b) the ion at $m / z 515$.

$271\left(\left[\mathrm{M}-\mathrm{H}-\mathrm{CH}_{2} \mathrm{O}\right]^{-}\right)$, originating from a retro-DielsAlder (RDA) reaction. ${ }^{19-21}$ Comparing these $\mathrm{MS}^{\mathrm{n}}$ data with the fragmentation of a standard quercetin solution (data not showed) it is possible to observe that they are very similar and so quercetin should be the aglycone of compound 7.

It is known that, despite the fact that any of the hydroxyl groups of the flavonoid aglycone can be glycosylated, certain positions are favoured. For flavonols the $3-\mathrm{OH}$ and $7-\mathrm{OH}$ positions are regular glycosylation sites. ${ }^{10}$ Even so, based only on $\mathrm{MS}^{\mathrm{n}}$ data, neither the nature of the hexoside residue nor the sugar linkage position to the aglycone could be determined. Thus, compound 7 was preliminary characterized as a quercetin-O-hexose.

Compound $8\left(\mathrm{t}_{\mathrm{R}}=10.3 \mathrm{~min}\right)$ gave a molecular ion $[\mathrm{M}-\mathrm{H}]^{-}$ at $m / z 477$ and its $\mathrm{MS}^{2}$ spectrum showed a fragment ion $\mathrm{Y}_{0^{-}}$at $\mathrm{m} / \mathrm{z} 315$ (loss of $162 \mathrm{Da}$ ), suggesting the presence of a hexoside residue. Fragmentation of the ion at $\mathrm{m} / \mathrm{z} 315$ was very similar to that of isorhamnetin reported in previously studies. ${ }^{14,22}$ So, compound 8 was tentatively identified as a isorhamnetin- $O$-hexoside.

Compounds $17 \quad\left(t_{R}=21.3 \mathrm{~min}\right)$ and $27 \quad\left(t_{R}=23.7 \mathrm{~min}\right)$ showed a very similar behaviour in the $\mathrm{MS}^{\mathrm{n}}$ experiments and gave deprotonated molecular ions $[\mathrm{M}-\mathrm{H}]^{-}$at $\mathrm{m} / \mathrm{z} 609$ and their $\mathrm{MS}^{2}$ spectra showed a fragment ion $[\mathrm{M}-\mathrm{H}-146]^{-}$at $\mathrm{m} / \mathrm{z} 463$ as base peak. The formation of the ion at $\mathrm{m} / \mathrm{z} 463 \mathrm{can}$ be assigned either to a loss of a rhamnose moiety or a coumaroyl group.

For both compounds the $\mathrm{MS}^{3}$ spectra gave a base peak ion at $m / z 301$, corresponding to the deprotaned aglycone $\left(\mathrm{Y}_{0^{-}}\right)$, due to the loss of an hexoside residue: the corresponding aglycone radical ion $\left[\mathrm{Y}_{0}^{-}-\mathrm{H}\right]^{-}$at $m / z 300(<30 \%$ of the base peak) was also observed.

The fragmentation of the ion at $\mathrm{m} / \mathrm{z} 301$ produced ions at $\mathrm{m} / \mathrm{z}$ $151\left({ }^{1,2} \mathrm{~A}^{-}-\mathrm{CO}\right), 179\left(\left[^{1,2} \mathrm{~A}^{-}-\mathrm{H}\right]\right)$ and $271\left(\left[\mathrm{M}-\mathrm{H}-\mathrm{CH}_{2} \mathrm{O}\right]^{-}\right)$, leading to the aglycone identification as quercetin.

Flavonols substituted at 3-OH position should present relative high intensity aglycone radical fragment sometimes higher than the $\mathrm{Y}_{0}^{-}$ion. ${ }^{23}$ Such a pattern was not observed for compounds 17 and 27; thus the glycosylation site cannot be surely confirmed. As mentioned above, either a malonyl or a rhamnosyl group could be attached to the hexoside residue but, based only on the $\mathrm{MS}^{\mathrm{n}}$ data, it is hard to clearly make the attribution of either to compound $\mathbf{1 7}$ or $\mathbf{2 7}$. However, it has been reported that, generally, flavonoid glycosides esterified

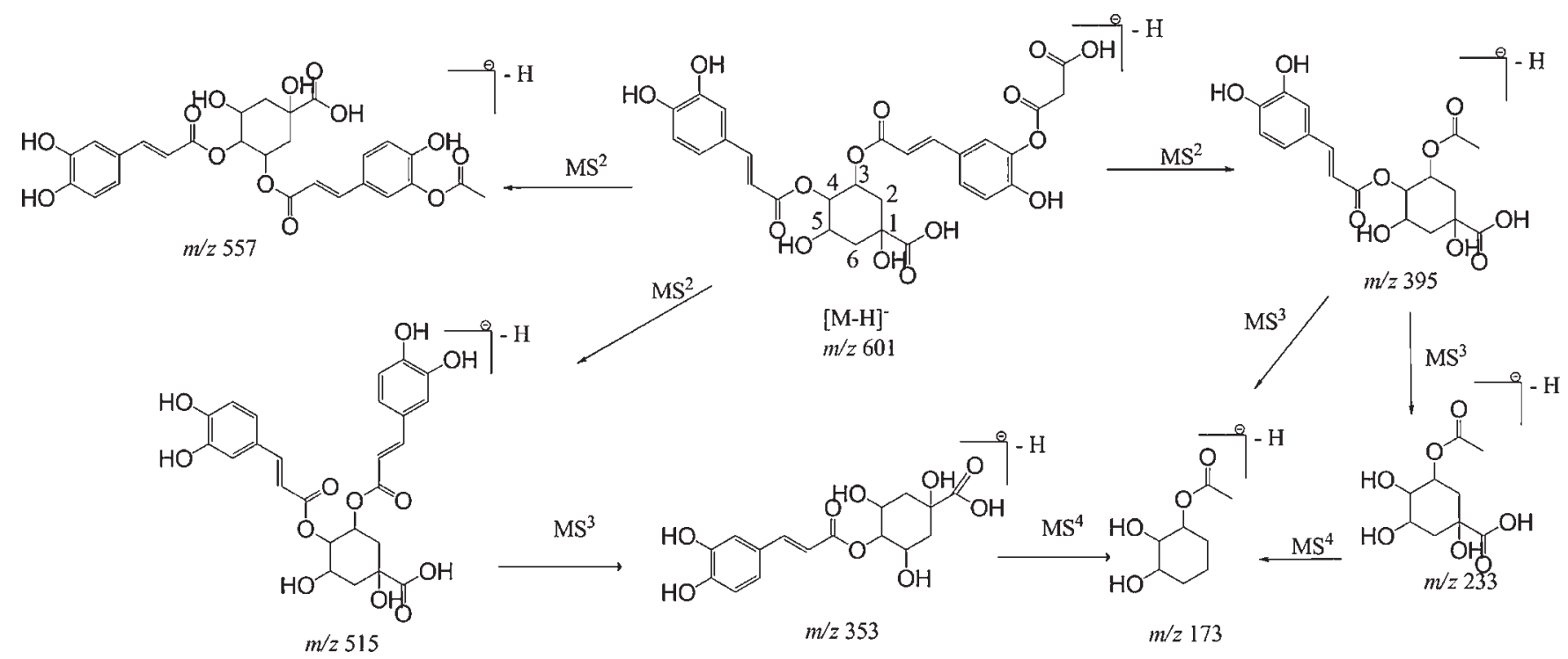

Scheme 1. Proposed fragmentation pathway for compound 13. 


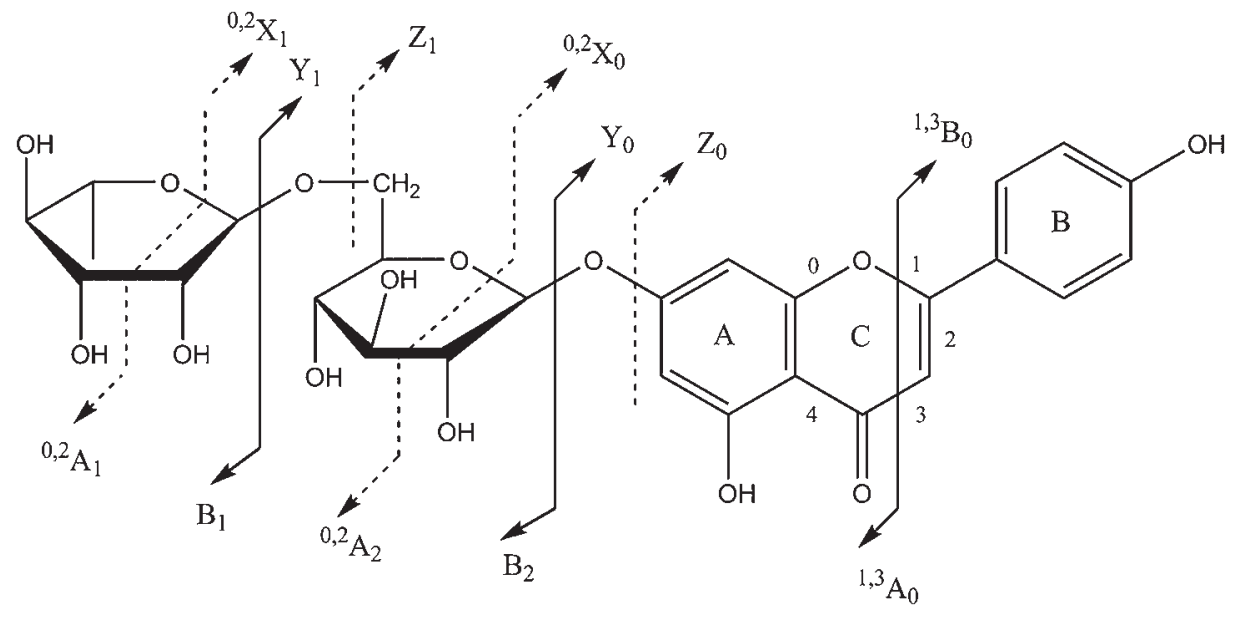

Figure 4. Ion nomenclature used for avonoid glycosides (illustrated on apigenin 7-O-rutinoside). ${ }^{18}$

with aromatic acids have higher retention times on RP-HPLC columns than diglycosides, monoglycosides and aglycones. $^{14}$

With no further information, compounds 17 and 27 were tentatively identified as a quercetin O-rhamnosylhexoside derivative and quercetin $O$-coumaroylhexoside, respectively.

Compound $19\left(t_{\mathrm{R}}=26.3 \mathrm{~min}\right)$ exhibited a $[\mathrm{M}-\mathrm{H}]^{-}$ion at $m / z$ 625. The $\mathrm{MS}^{2}$ spectrum of this ion showed a fragment at $m / z$ 301, corresponding to the loss of $324 \mathrm{Da}$, which indicates two hexoside moieties linked at the same position of the aglycone. ${ }^{24}$ Fragmentation of the resulting aglycone ion, $\mathrm{Y}_{0}^{-}$, produced characteristic fragments of quercetin. This compound was thus classified as a quercetin- $O$-dihexoside.
Compound $20\left(t_{\mathrm{R}}=27.5 \mathrm{~min}\right)$ gave a $[\mathrm{M}-\mathrm{H}]^{-}$ion at $m / z 711$. The fragmentation showed a loss of $44 \mathrm{Da}$, which indicates a decarboxylation from a dicarboxylic acid linked to the flavonoid glycoside. The $\mathrm{MS}^{3}$ spectrum showed a base peak ion at $m / z 505\left(\mathrm{Y}_{0}^{7-}\right)$ originating from the loss of a hexoside moiety $(162 \mathrm{Da})$ and also a very intense peak at $m / z 301\left(\mathrm{Y}_{0}^{3-}\right)$ (Fig. 5).

This type of fragmentation (Scheme 2), in which the loss of a sugar unit gives the most abundant base peak different from the base peak of the aglycone, indicates that there is a glycosylation in more than one phenolic hydroxyl group of the aglycone. ${ }^{25}$ The fragmentation of the ion at $\mathrm{m} / \mathrm{z} 505$ yielded the aglycone fragment ion at $m / z$ 301, by the loss of 204 Da from the decarboxylated malonyl group linked to the

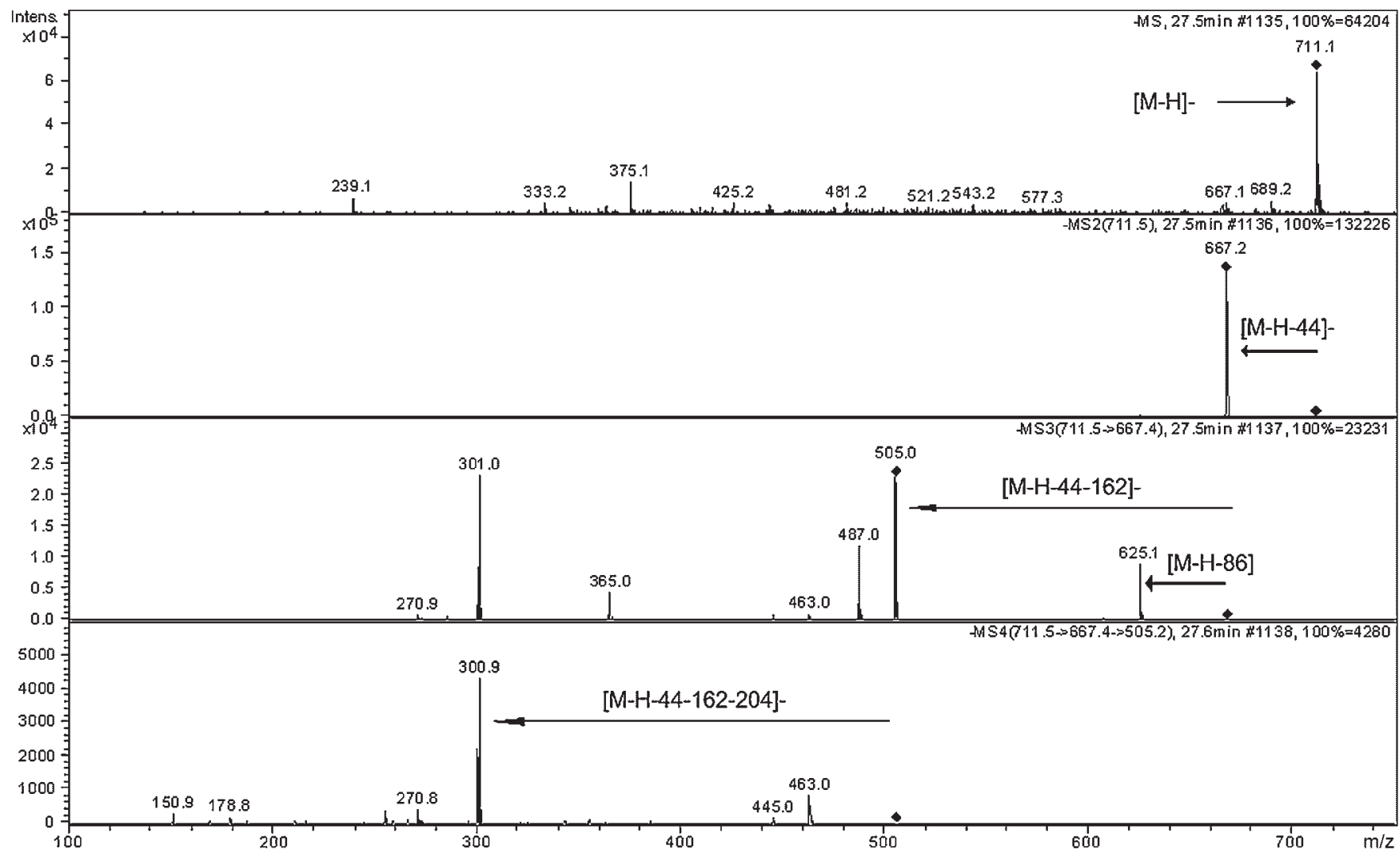

Figure 5. ESI-MS ${ }^{n}$ negative mode of compound 20. Sequential fragmentation, $\mathrm{MS}^{\mathrm{n}}(\mathrm{n}=2-4)$, of the ion at $m / z 711$. 


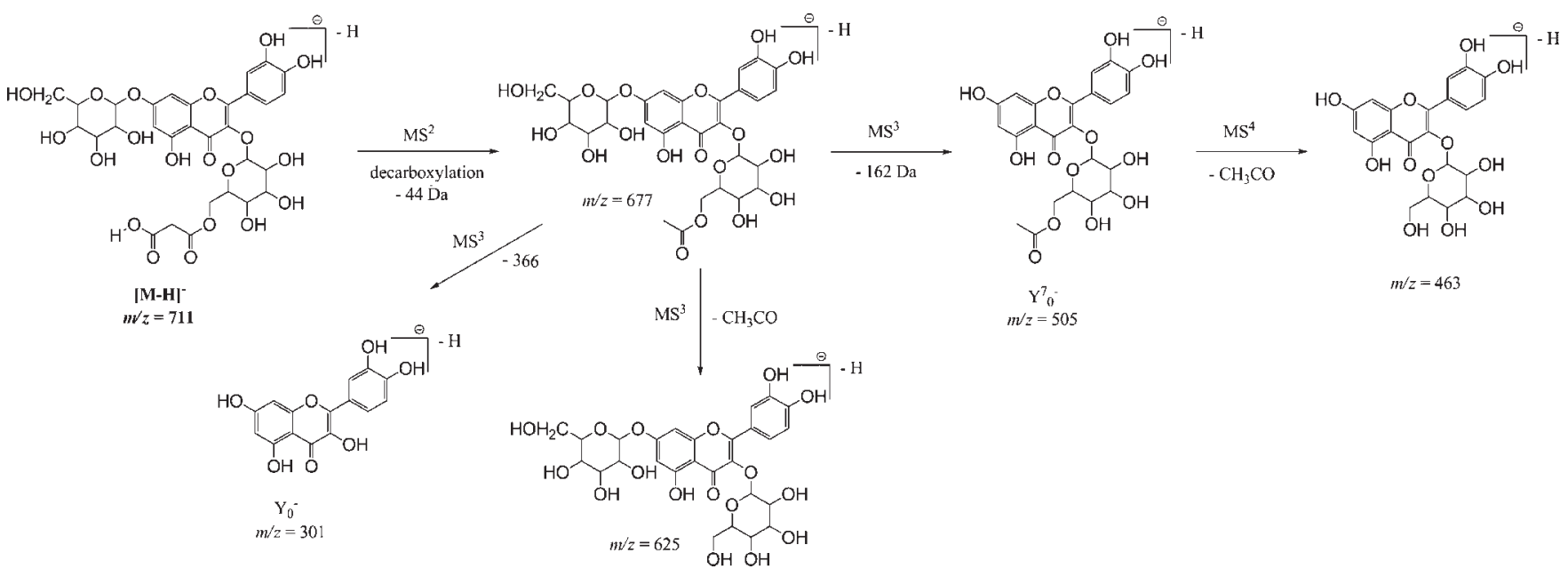

Scheme 2. Proposed fragmentation pathway for compound 20.

hexoside residue. The aglycone was identified by $\mathrm{MS}^{\mathrm{n}}$ fragmentation of the ion at $\mathrm{m} / \mathrm{z} 301$ as being quercetin.

The glycosylation sites were established attending to the guidelines presented by Ablajan et al. ${ }^{9}$ In the $\mathrm{MS}^{4}$ spectrum, the intensity of the fragment $\mathrm{Y}_{0}^{-}$is higher than that of fragment $\left[\mathrm{Y}_{0}^{-}-\mathrm{H}\right]^{-}$, which implies a cleavage of an hexoside group at the $3-\mathrm{OH}$ position. Therefore, the first sugaraglycone bond to cleave is at the 7-OH position.

The exact location of the malonyl group on the hexoside part is difficult to define on the basis of obtained $\mathrm{MS}^{\mathrm{n}}$ data, but it appears to be predominantly located at the 6-position of a hexoside moiety. ${ }^{10}$ According to these $\mathrm{MS}^{\mathrm{n}}$ data, compound 20 was plausible identified as quercetin-7-Ohexoside-3-O-(malonyl)hexoside.

Compound $22\left(\mathrm{t}_{\mathrm{R}}=30.3 \mathrm{~min}\right)$ exhibited a $[\mathrm{M}-\mathrm{H}]^{-}$ion at $\mathrm{m} / \mathrm{z} 629$ and was identified as being a quercetin-O-hexoside derivative based on the $\mathrm{MS}^{\mathrm{n}}$ fragmentation. The $\mathrm{MS}^{2}$ spectrum showed a base peak ion at $\mathrm{m} / \mathrm{z} 463$, which corresponds to the loss of $166 \mathrm{Da}$ (this fragment could not be identified based in the available data). The fragmentation of the ion at $m / z 463$ led to the formation of the same fragment ions detected for compound 7 .

Compounds $29 \quad\left(t_{R}=28.3 \mathrm{~min}\right)$ and $30 \quad\left(t_{R}=29.7 \mathrm{~min}\right)$ exhibited a very similar $\mathrm{MS}^{\mathrm{n}}$ pattern and gave a molecular ion $[\mathrm{M}-\mathrm{H}]^{-}$at $m / z$ 593. Their $\mathrm{MS}^{2}$ spectra contained a base peak ion [M-H-146-162] $]^{-}$at $m / z 285$ and a $[\mathrm{M}-\mathrm{H}-146]^{-}$ion at $m / z 447$ ( $10 \%$ of the base peak). As already known, ${ }^{26}$ the neutral loss of $146 \mathrm{Da}$ is characteristic of a coumaroyl group which was confirmed by the formation of a [coumaroylhexose- $-\mathrm{H}]^{-}$ion at $\mathrm{m} / \mathrm{z} 307$. According to these considerations compounds 29 and 30 were preliminarily characterized as acylated flavonoid glycosides.

The peak at $\mathrm{m} / \mathrm{z} 285$ corresponds to the aglycone $\left(\mathrm{Y}_{0^{-}}-\mathrm{H}\right)$ and its $\mathrm{MS}^{\mathrm{n}}$ spectra showed a $\left(\mathrm{Y}_{0}^{-}-\mathrm{H}-\mathrm{CO}\right)$ ion at $m / z 257$, a $\left(\mathrm{Y}_{0^{-}}-2 \mathrm{CO}\right)$ ion at $m / z 229$ and, as base peak, an ion at $m / z 151$ $\left({ }^{1,3} \mathrm{~A}^{-}\right)$, produced from a RDA reaction. ${ }^{14}$ These RDA fragments are consistent with those found for a standard solution of kaempferol (MS ${ }^{\mathrm{n}}$ fragmentation data not shown).

Theoretically, any of the kaempferol hydroxyl groups can be glycosylated, although certain positions are favoured: the $3-\mathrm{OH}$ and 7-OH are the most common glycosylated positions.
As stated before, for flavonols glycosylated at the 3-OH position, the relative abundance of radical aglycone ion $\left(\left[\mathrm{Y}_{0}^{-} \mathrm{H}\right]^{-} \cdot\right)$ is very pronounced. ${ }^{23}$ However, this radical fragment was detected for both compounds but with a very low relative intensity ( $\sim 4 \%$ of the base peak). So, glycosylation at the 3-OH position is not evident, leaving the 7-OH and $4{ }^{\prime}-\mathrm{OH}$ positions as the most probable sites of glycosylation for these compounds. The $5-\mathrm{OH}$ position is also available but 5-O-glycosides are very rare for compounds with a carbonyl at position 4, since the 5-OH group participates in hydrogen bonds with the adjacent 4-carbonyl group. ${ }^{10}$

As already mentioned, compounds 29 and $\mathbf{3 0}$ have an acyl group in their structures, but the exact location of the acyl group on the hexoside moiety is difficult to define based only on $\mathrm{MS}^{\mathrm{n}}$ data. Acyl groups are predominantly located at the 6-position of a hexoside moiety, ${ }^{21}$ but only when a ${ }^{0,4} \mathrm{X}$ fragment is present in the spectrum can the location at the 6-position be confirmed, which did not happen in this particular case.

With no further information, it was assumed that compounds 29 and 30 are kaempferol 7-O-coumaroylhexoside and kaempferol 4'-O-coumaroylhexoside.

Compound $28\left(\mathrm{t}_{\mathrm{R}}=27.7 \mathrm{~min}\right)$ gave a $[\mathrm{M}-\mathrm{H}]^{-}$ion at $\mathrm{m} / \mathrm{z} 285$ and a $[2 \mathrm{M}-\mathrm{H}]^{-}$ion at $m / z 571(15.4 \%$ of base peak). The fragmentation of the molecular ion gave rise to several fragment ions at $m / z 243\left(\left[\mathrm{M}-\mathrm{H}-\mathrm{C}_{2} \mathrm{H}_{2} \mathrm{O}\right]^{-}\right), 241([\mathrm{M}-\mathrm{H}-$ $\left.\left.\mathrm{CO}_{2}\right]^{-}\right), 217\left(\left[\mathrm{M}-\mathrm{H}-\mathrm{C}_{3} \mathrm{O}_{2}\right]^{-}\right), 175\left(\left[\mathrm{M}-\mathrm{H}-\mathrm{C}_{3} \mathrm{O}_{2}-\mathrm{C}_{2} \mathrm{H}_{2} \mathrm{O}\right]^{-}\right)$, 199, $151\left({ }^{1,3} \mathrm{~A}^{-}\right)$and $135\left({ }^{1,3} \mathrm{~B}^{-}\right)$. This compound was identified as luteolin by comparison of its $\mathrm{MS}^{\mathrm{n}}$ fragmentation pattern with that of a reference standard (data not shown) and literature data. ${ }^{19}$

Compound $24\left(\mathrm{t}_{\mathrm{R}}=11.0 \mathrm{~min}\right)$ exhibited a $[\mathrm{M}-\mathrm{H}]^{-}$ion at $\mathrm{m} / \mathrm{z}$ 461. When submitted to further fragmentation this ion readily eliminated a glucuronic acid residue (observed by the loss of $176 \mathrm{Da}$ ) to produce the deprotonated aglycone ion $\mathrm{Y}_{0^{-}}$ at $m / z 285$. The glucuronic acid residue was confirmed by the $\mathrm{MS}^{2}$ ions at $\mathrm{m} / \mathrm{z} 357$ and 327 . The $\mathrm{MS}^{3}$ spectrum of the aglycone ion gave fragments at $\mathrm{m} / \mathrm{z} 243,217,199$ and 175, characteristic ions of luteolin as described above. The favoured substitution position for flavones, like luteolin, is 
the $7-\mathrm{OH}$ position. ${ }^{10}$ Therefore, compound 24 was characterized as luteolin-7-O-glucuronide.

With a retention time of $13.2 \mathrm{~min}$, compound 25 originated a molecular ion $[\mathrm{M}-\mathrm{H}]^{-}$at $\mathrm{m} / \mathrm{z} 431$ and subsequent fragmentation showed the loss of $162 \mathrm{Da}$. The formed ion corresponds to a deprotonated aglycone ion at $\mathrm{m} / \mathrm{z} 269$. Prasain et al. ${ }^{27}$ reported that glycosides of genistein (isoflavone) and apigenin (flavone) have $[\mathrm{M}-\mathrm{H}]^{-}$ions at $\mathrm{m} / \mathrm{z} 431$ and these two compounds can only be distinguished by their $\mathrm{MS}^{3}$ spectrum. $\mathrm{MS}^{\mathrm{n}}$ fragmentation of the ion at $\mathrm{m} / \mathrm{z}$ 269 gave a unique product ion $(\mathrm{m} / \mathrm{z} 133$ for genistein and $\mathrm{m} / \mathrm{z}$ $149\left({ }^{1,4} \mathrm{~B}+2 \mathrm{H}\right)$ for apigenin). According to this information and regarding $\mathrm{MS}^{\mathrm{n}}$ data obtained for compound 25 , this was plausibly identified as apigenin-7-O-glucoside, since the glycosylation site of flavones is preferential at the $7-\mathrm{OH}$ position. These results were later confirmed by the analysis of a standard solution of apigenin-7-O-glucoside under the same LC-DAD/ESI-MS ${ }^{\mathrm{n}}$ conditions.

Compound 31 occurs at a higher retention time $\left(t_{R}=33.7 \mathrm{~min}\right)$ and was identified as apigenin. It displayed a $[\mathrm{M}-\mathrm{H}]^{-}$ion at $m / z 269$ and, by $\mathrm{MS}^{\mathrm{n}}$ fragmentation, the following fragments were observed at $m / z 225$, [M-H- $\left.-\mathrm{CO}_{2}\right]^{-}$; $201,\left[\mathrm{M}-\mathrm{H}-\mathrm{C}_{3} \mathrm{O}_{2}\right]^{-} ; 151,{ }^{1,3} \mathrm{~A} ; 149,\left({ }^{1,4} \mathrm{~B}+2 \mathrm{H}\right)$. This fragmentation pattern matches the one observed for a standard solution of apigenin.

\section{Identification of a protocatechuic and caffeic acid derivatives $(18,15,33)$}

Compound $18\left(t_{R}=25.0 \mathrm{~min}\right)$ showed a molecular ion [M$\mathrm{H}^{-}$at $\mathrm{m} / \mathrm{z} 445$. The $\mathrm{MS}^{2}$ spectrum showed the loss of a fragment of $208 \mathrm{Da}$, due to combined losses of $162 \mathrm{Da}$ and $46 \mathrm{Da}$. The loss of $46 \mathrm{Da}$ was supported by the formation of a $[\mathrm{M}-\mathrm{H}-46]^{-}$ion at $m / z 399$.

Fragmentation of the ion at $m / z 237$ gave an ion at $m / z 153$ that could possibly be from a protocatechuic acid unit. ${ }^{28}$ However, the intensity of this fragment was not enough to perform further fragmentation in order to confirm the presence of protocatechuic acid. Compound $\mathbf{1 8}$ was thus speculatively classified as a protocatechuic acid derivative; it is present in trace amounts only in the total plant extract.

Compound $15\left(t_{R}=18.2 \mathrm{~min}\right)$ was identified as a caffeic acid derivative, based on the $\mathrm{MS}^{\mathrm{n}}$ pattern of fragmentation. It showed a $[\mathrm{M}-\mathrm{H}]^{-}$ion at $m / z 625$ which when fragmented led to the formation of a product ion at $\mathrm{m} / \mathrm{z} 473$ (loss of $152 \mathrm{Da}$ ). Further fragmentation of this ion produced a $\mathrm{MS}^{3}$ spectrum with a base peak at $m / z 341$ that corresponds to the loss of 132 $\mathrm{Da}$, probably resulting from neutral loss of a pentose (arabinose, xylose or apiose) or a tartaric acid unit. The ion at $\mathrm{m} / \mathrm{z} 341$ has already been assigned to caffeic acid hexoside, which was confirmed by the fragment ion at $\mathrm{m} / \mathrm{z}$ 179 [caffeic acid-H] ${ }^{-}$obtained in the $\mathrm{MS}^{4}$ spectrum. ${ }^{24}$ It is noteworthy that this compound was not detected in the flowers extract but was present in all the other morphological parts.

Both compounds $32\left(t_{R}=26.4 \mathrm{~min}\right)$ and $33\left(t_{R}=27.9 \mathrm{~min}\right)$ showed $[\mathrm{M}-\mathrm{H}]^{-}$ions at $m / z 583$ and they have similar $\mathrm{MS}^{2}$ spectra with a base peak at $m / z 421$, resulting from the neutral loss of $162 \mathrm{Da}$. However, the $\mathrm{MS}^{3}$ and $\mathrm{MS}^{4}$ spectra of these two compounds are quite different. For compound 32, the fragment ion at $m / z 421$ readily loses $162 \mathrm{Da}$ to produce an ion at $m / z 259$, which when fragmented in $\mathrm{MS}^{4}$ gave a peak at $m / z$
173. The nature of the aglycone could not be determined by these $\mathrm{MS}^{\mathrm{n}}$ results only; however, it is clear that there is successive loss of two residues of $162 \mathrm{Da}$, probably hexosides.

For compound 33, the MS ${ }^{3}$ spectrum of the ion at $m / z 421$ exhibited a base peak at $m / z 353$ and several peaks with high relative intensity at $m / z 335(74.5 \%), 259$ (72.5\%), $179(43.2 \%)$ and $173(53.6 \%)$. The $\mathrm{MS}^{4}$ spectrum of the fragment at $m / z 353$ exhibited as base peak a fragment at $m / z 179$ and a very intense peak at $\mathrm{m} / \mathrm{z} 173$ ( $95.7 \%$ of the base peak). The fragment ion at $m / z 179$ indicates the presence of a caffeic acid derivative but no other identification can be performed based on the available data. Therefore, compound 33 was characterized as a caffeic acid hexoside derivative.

\section{Unidentified compounds $(2,3,6,23,34)$}

Other peaks were observed and denominated as compounds $2,3,6,23$ and 34 . However, the elucidation of their structures based solely on $\mathrm{MS}^{\mathrm{n}}$ data has not been completely reached yet.

At a retention time of $7.5 \mathrm{~min}$ we observed an intense peak that exhibited a $[\mathrm{M}-\mathrm{H}]^{-}$ion at $m / z$ 429. The $\mathrm{MS}^{2}$ spectrum showed an ion at $m / z 393$, resulting from the loss of $36 \mathrm{Da}$. $\mathrm{MS}^{\mathrm{n}}$ fragmentation gave ions at $\mathrm{m} / \mathrm{z} 149$ (loss of $244 \mathrm{Da}$ ) and 131 (loss of 18 Da due to a molecule of water). This peak was designated as compound 6 and showed three maximum absorptions at 230-245, 280-300 and $340 \mathrm{~nm}$. Nevertheless, it was not possible to identify its structure. It must be mentioned that this compound was found in all plant extracts with the exception of the stems extract.

Compound $23\left(t_{\mathrm{R}}=34.8 \mathrm{~min}\right)$ gave a $[\mathrm{M}-\mathrm{H}]^{-}$ion at $\mathrm{m} / \mathrm{z} 331$ and additional fragmentation formed an ion at $\mathrm{m} / \mathrm{z} 155$ which corresponds to the loss of $176 \mathrm{Da}$ (probably a glucuronide residue). The $\mathrm{MS}^{3}$ and $\mathrm{MS}^{4}$ spectra showed sequential losses of $15 \mathrm{Da}$ that indicates the presence of methyl groups.

\section{CONCLUSIONS}

A simple and sensitive LC-DAD/ESI-MS ${ }^{\mathrm{n}}$ method has been used for the comprehensive separation and identification of phenolic compounds in different morphological parts of Helichrysum devium. Abundant $[\mathrm{M}-\mathrm{H}]^{-}$ions were observed in ESI-MS $^{n}$ negative mode, and were used to identify molecular masses of the detected compounds. A total of 34 compounds found in the total aerial parts, leaves, flowers and stems were characterized or tentatively identified based on the $\mathrm{MS}^{\mathrm{n}}$ fragmentation behaviour, UV spectra and retention times. Positive identification was facilitated for three of these compounds using authentic standards.

Quinic acid derivatives were found to be the major constituents of Helichrysum devium extracts analyzed. A 206 Da neutral loss from $[\mathrm{M}-\mathrm{H}]^{-}$ions of malonylcaffeoylquinic acid isomers was explored for the first time by our LC-DAD/ ESI-MS ${ }^{\mathrm{n}}$ method, and indicated that the malonyl group is attached to one caffeoyl group rather than being linked to the quinic acid structure.

The flowers extract revealed the presence of a much higher variety of phenolic compounds, namely flavonoids, most of them as glycosides and/or esterified with acyl groups. A large number of compounds were described for the first time in Helichrysum species using $\mathrm{LC} / \mathrm{MS}^{\mathrm{n}}$ as an analytical tool. The antimicrobial and antioxidant properties of these extracts have been investigated and will be reported elsewhere. 


\section{Acknowledgements}

S. Gouveia is grateful to Fundação para a Ciência e Tecnologia (Portugal) for a PhD grant SFRH/BD/24227/2005. This work made use of equipment from MS National Network REDE/1508/REM/2005. The authors wish to thank taxonomist Fátima Rocha for plant identification.

\section{REFERENCES}

1. Lourensa ACU, Viljoenb AM, Heerden FRv. J. Ethnopharm. 2008; 119: 630.

2. Carini M, Aldini G, Furlanetto S, Stefani R, Facino RM. J. Pharmaceut. Biomed. Anal. 2001; 24: 517.

3. Al-Rehaily AJ, Albishi OA, El-Olemy MM, Mossa JS. Phytochemistry. 2008; 69: 1910.

4. Clifford MN. J. Sci. Food Agric. 2000; 80: 1033.

5. Naczk M, Shahidi F. J. Pharmaceut. Biomed. Anal. 2006; 41: 1523.

6. Fang Z, Zhang M, Wang L. Food Chem. 2007; 100: 845.

7. Grotewold E (ed). The Science of Flavonoids. Springer: Heidelberg, 2006.

8. Ye M, Han J, Chen H, Zheng J, Guo D. J. Am. Soc. Mass Spectrom. 2007; 18: 82.

9. Ablajan K, Abliz Z, Shang X-Y, He J-M, Zhang R-P, Shi J-G. J. Mass Spectrom. 2006; 41: 352.

10. Cuyckens F, Claeys M. J. Mass Spectrom. 2004; 39: 1.

11. Rijke Ed, Zappey H, Ariese F, Gooijer C, Brinkman UAT. J. Chromatogr. A 2003; 984: 45.
12. Sannomiya M, Santos LCd, Carbone V, Napolitano A, Piacente S, Pizza C, Souza-Brito ARM, Vilegas W. Rapid Commun. Mass Spectrom. 2007; 21: 1393.

13. Han J, Ye M, Guo H, Yang M, Wang B-R, Guo D-A. I. Pharmaceut. Biomed. Anal. 2007; 44: 430.

14. Ye M, Yan Y, Guo D-A. Rapid Commun. Mass Spectrom. 2005; 19: 1469.

15. Clifford MN, Johnston KL, Knight S, Kuhnert N. J. Agric. Food Chem. 2003; 51: 2900.

16. Clifford MN, Knight S, Kuhnert N. J. Agric. Food Chem. 2005; 53: 3821 .

17. Zhang Y, Shi P, Qu H, Cheng Y. Rapid Commun. Mass Spectrom. 2007; 21: 2971.

18. Ma YL, Li QM, Heuvel HVd, Claeys M. Rapid Commun. Mass Spectrom. 1997; 11: 1357.

19. Fabre N, Rustan I, Hoffmann Ed, Quetin-Leclercq JL. J. Am. Soc. Mass Spectrom. 2001; 12: 707.

20. Lhuillier A, Fabre N, Moyano F, Martins N, Claparols C, Fourasté I, Moulis C. J. Chromatogr. A 2007; 1160: 13.

21. Justesen U. J. Chromatogr. A 2000; 902: 369.

22. Han J, Ye M, Qiao X, Xu M, Wang B-R, Guo D-A. J. Pharmaceut. Biomed. Anal. 2008; 47: 516.

23. Cuyckens F, Claeys M. J. Mass Spectrom. 2005; 40: 364.

24. Schütz K, Kammerer DR, Carle R, Schieber A. Rapid Commun. Mass Spectrom. 2005; 19: 179.

25. Llorach R, Martínez-Sánchez A, Tomás-Barberán FA, Gil MI, Ferreres F. Food Chem. 2008; 108: 1028.

26. Parejo I, Jáuregui O, Viladomat F, Bastida J, Codina C. Rapid Commun. Mass Spectrom. 2004; 18: 2801.

27. Prasain JK, Wang C-C, Barnes S. Free Radical Biol. Med. 2004; 37: 1324 .

28. Liu A-H, Guo H, Ye M, Lin Y-H, Sun J-H, Xu M, Guo D-A. J. Chromatrogr. A 2007; 1161: 170. 